\title{
IMPLIKASI MEKANISME SELEKSI TERHADAP INDEPENDENSI DAN INTEGRITAS HAKIM KONSTITUSI DI INDONESIA
}

\author{
IMPLICATION OF SELECTION MECHANISM TOWARDS \\ INTEGRITY AND INDEPENDENCY OF CONSTITUTIONAL \\ COURT JUDGES IN INDONESIA
}

\author{
Iwan Satriawan \\ Universitas Muhammadiyah Yogyakarta \\ E-mail: iwansatriawan@umy.ac.id \\ Tanto Lailam \\ Universitas Muhammadiyah Yogyakarta \\ E-mail: tanto_lailam@umy.ac.id
}

\begin{abstract}
Cases of bribery and violations of the code of ethics that occur in the constitutional court justices raise serious questions about the quality of the independence and integrity of the Constitutional Court which have an impact on decreasing public trust in the Constitutional Court. The research aims to study the root causes of problems that occur to the Constitutional Court and specifically evaluate the selection mechanism for the appointment of constitutional court justices in Indonesia and what are the implications for the independence and integrity of constitutional court justices. This study also aims to provide recommendations for a better, more transparent and accountable selection mechanism model in the selection of Constitutional Court Justices in order to produce justices who are more independent and with integrity. The research method used is normative-empirical, with data collection techniques through interviews and literature study. The results of the study indicate that there is a significant correlation between the selection mechanism for constitutional court justices and the quality of the constitutional court justices produced from the mechanism. With a good and transparent process, justices with integrity and independence will be born. In addition, the competence of judges affects the performance of the constitutional judges themselves. The study also concluded that the selection mechanism for constitutional judges which tends to be closed and unaccountable will produce constitutional court justices who do not have integrity and are not independent.
\end{abstract}

\section{Keyword(s): Constitutional Court Justices; Selection Mechanism; Judicial Independence and Integrity.}

\begin{abstract}
Abstrak
Kasus-kasus suap dan pelanggaran kode etik yang terjadi pada hakim konstitusi menimbulkan pertanyaan serius tentang kualitas independensi dan integritas dari hakim Konstitusi yang berdampak pada menurunnya kepercayaan publik kepada Mahkamah Konstitusi. Penelitian ini bertujuan untuk mengkaji akar permasalahan yang terjadi pada kasus-kasus yang terjadi pada hakim MK dan secara spesifik mengevaluasi mekanisme seleksi pengangkatan hakim konstitusi di Indonesia dan bagaimanakah implikasinya terhadap independensi dan integritas hakim konstitusi. Penelitian ini juga bertujuan memberikan rekomendasi model mekanisme seleksi
\end{abstract}


yang lebih baik, transparan, dan akuntabel dalam seleksi hakim MK agar menghasilkan hakim yang lebih independen dan berintegritas. Metode penelitian yang digunakan adalah normatif-empiris, dengan teknik pengumpulan data melalui interview dan studi pustaka. Hasil penelitian ini menunjukan bahwa adanya korelasi yang signifikan antara mekanisme seleksi hakim konstitusi dan kualitas dari hakim konstitusi yang lahir dari mekanisme tersebut. Dengan proses yang baik dan transparan, akan melahirkan hakim yang berintegritas dan independen. Selain itu juga, kompetensi hakim mempengaruhi kinerja dari hakim konstitusi itu sendiri. Penelitian juga menyimpulkan bahwa dengan mekanisme seleksi hakim konstisusi yang cenderung tertutup dan tidak akuntabel akan melahirkan hakim konstitusi yang tidak berintegritas dan tidak independen.

\section{Kata Kunci: Hakim Konstitusi; Independensi dan Integritas Hakim Konstitusi; Me- kanisme Seleksi.}

\section{PENDAHULUAN}

Pada tahun 2013 Ketua Mahkamah Konstitusi Indonesia, Akil Mokhtar, ditangkap oleh Komisi Pemberantasan Korupsi (KPK). ${ }^{1}$ Kemudian, kasus suap berikutnya menimpa hakim konstitusi Patrialis Akbar dan kasus pelanggaran kode etik yang dilakukan 2 kali oleh hakim konstitusi Arief Hidayat. ${ }^{2}$ Terakhir, kasus yang menarik dievaluasi adalah skandal pemberian gelar kehormatan oleh Presiden kepada 6 orang hakim konstitusi yang masih aktif. ${ }^{3}$ Jika dilihat kasus yang terjadi menunjukkan bahwa independensi lembaga peradilan dan integritas hakim konstitusi selalu mendapat ancaman dan godaan dari kekuasaan dan uang. ${ }^{4}$ Kasus-kasus suap dan pelanggaran kode etik yang melibatkan hakim konstitusi merupakan contoh kasus bahwa mekanisme seleksi hakim konstitusi perlu dievaluasi.

Dalam sistem pengangkatan haki konstitusi di Indonesia misalnya, 6 dari 9 hakim konstitusi adalah usulan dari presiden (3 orang) dan 3 orang berasal usulan DPR. Dengan komposisi seperti itu sebenarnya eksekutif memiliki kecenderungan mampu menempatkan orangnya dengan jumlah lebih banyak di jajaran hakim Mahkamah Konstitusi. Minimal dengan komposisi 5: 4 atau 6:3 jika komposisi di DPR dikuasai secara mutlak oleh rezim yang berkuasa. Dengan demikian sebenarnya sangat sulit menemukan secara ideal berjalannya mekanisme checks and balances yang efektif dari lembaga peradilan seperti Mahkamah Konstitusi terhadap kekuasaan eksekutif maupun legislatif dengan menggunakan model seperti yang digunakan oleh Indonesia dan beberapa negara lain di dunia saat ini. Oleh karena itu, mekanisme checks and balances akan berjalan dengan baik ketika lembaga kehakiman dipastikan bersifat independen

\footnotetext{
${ }^{1}$ Lihat Ihsanuddin, 2013, Akil Mochtar Ditangkap, Hakim dan Mantan Hakim MK Berembuk, https://nasional.kompas. com/read/2013/10/03/2041208/Akil.Mochtar.Ditangkap.Hakim.dan.Mantan.Hakim.MK.Berembuk, diakses pada 20 September 2020 .

${ }^{2}$ Lihat Abba Gabrilin, 2017, Patrialis Akbar Ditangkap bersama Seorang Perempuan di Grand Indonesia, https://nasional.kompas.com/read/2017/01/26/20172511/patrialis.akbar.ditangkap.bersama.seorang.perempuan.di.grand.indonesia, diakses pada 20 September 2020.

${ }^{3}$ Sania Mashabi, 2020, Penganugerahan Bintang Mahaputera pada 6 Hakim MK Dinilai Berpotensi Pengaruhi Independensi,https://nasional.kompas.com/read/2020/11/12/22110041/penganugerahan-bintang-mahaputera-pada-6-hakim-mk-dinilai-berpotensi?page=all, diakses pada 25 Nopember 2020

${ }^{4}$ Hendrianto, The Rise and Fall of Heroic Chief Justices, Constitutional Politics and Judicial Leadership in Indonesia, Washington International Law Journal, 2016, Vol.25 No.3, hlm. 67-68; Lihat juga Reid Mortensen dan Richard Devlin, Special Issue: The Ethics of Judicial Appointments, Legal Ethics, 2017, Vol 20 No. 1, hlm. 1-3.
} 
dan imparsial, ${ }^{5}$ sehingga mekanisme seleksi hakim konstitusi harus bisa menjamin lahirnya hakim yang punya kapasitas dan integritas.

Oleh karena itu, penelitian ini akan mengevaluasi pengaruh model mekanisme seleksi pengangkatan hakim konstitusi terhadap independensi lembaga peradilan dan integritas hakim konstitusi di Indonesia. Tujuan khusus penelitian ini adalah melakukan kajian dan evaluasi yang lebih mendalam tentang kelebihan dan kekurangan model pengangkatan hakim konstitusi sekarang dalam rangka merumuskan model mekanisme seleksi hakim konstitusi yang lebih baik ke depan.

Secara teoritik, keberadaan lembaga peradilan yang independen dalam sebuah negara sangat urgen karena lembaga peradilan memainkan peranan yang penting dalam menjaga keseimbangan hubungan kekuasaan eksekutif, legislatif dan warga negara. Artinya jika lembaga peradilan mampu bersikap independen ${ }^{6}$, maka konsolidasi demokrasi di negara tersebut akan berjalan dengan baik karena berjalannya mekanisme checks and balances. Mekanisme seleksi yang transparan dianggap lebih menjamin munculnya hakim konstitusi yang memiliki syarat kapasitas dan integritas.

Penelitian ini bertujuan untuk mengkaji akar permasalahan munculnya kasuskasus suap dan pelanggaran kode etik yang menimpa hakim konstitusi. Penelitian ini secara spesifik akan mengevaluasi mekanisme seleksi hakim konstitusi di Indonesia untuk menemukan kelebihan dan kekurangan mekanisme seleksi yang ada sekarang. Penelitian ini juga akan merumuskan model ideal kebijakan dalam pengangkatan hakim konstitusi. Rekomendasi model ideal pengangkatan hakim konstitusi akan bermanfaat bagi pengembangan lembaga peradilan di Indonesia

Penelitian hukum merupakan penelitian yang diterapkan atau diberlakukan khusus pada ilmu hukum, yang membantu pengembangan ilmu hukum dalam mengungkap suatu kebenaran hukum, ${ }^{7}$ Penelitian yang dipilih adalah penelitian hukum normatif dan penelitian empiris. Penelitian hukum normatif adalah penelitian hukum yang meletakan hukum sebagai sebuah bangunan sistem norma. Penelitian hukum doktrinal dalam hal ini digunakan beberapa pendekatan, meliputi: (1) pendekatan perundang-undangan, dilakukan dengan cara menelaah peraturan perundang-undangan yang berkaitan dengan masalah hukum yang dikaji; (2) pendekatan analitis, bertujuan untuk mengkaji implementasi istilah-istilah hukum dalam berbagai undang-undang ataupun putusan pengadilan; (3) pendekatan kasus, telaah berbagai kasus problem pengangkatan hakim konstitusi. ${ }^{8}$ Penelitian hukum empiris, yang merupakan penelitian yang mengutamakan data primer yang berasal dari lapangan (realitas hukum) yang dilakukan dengan melakukan wawancara dengan beberapa responden, seperti para ahli dan para mantan calon hakim konstitusi yang mengalami proses seleksi hakim konstitusi di periode mereka masing-masing.

\footnotetext{
${ }^{5}$ Lihat Joanna M. Shepherd, Money, Politics, and Impartial Justice, Duke Law Journal, 2009, Vol.58, hlm. 632

${ }^{6}$ Kusnu Goesniadhie S, Prinsip Pengawasan Independensi Hakim, Jurnal Hukum, 2007, Vol.14 No.3, hlm. 445.

${ }^{7}$ F. Sugeng Istanto, 2007, Penelitian Hukum, CV. Ganda, Yogyakarta, hlm. 29.

8 Johnny Ibrahim, 2005, Teori \& Metodologi Penelitian Hukum Normatif, Bayumedia Publising, Malang, hlm. 300.
} 
Teknik pengumpulan data dilakukan dengan dua cara: penelitian kepustakaan (library research) bertujuan untuk menelaah data primer (bahan hukum primer, bahan hukum sekunder, dan bahan hukum tersier). Untuk penelitian empiris dilakukan dengan melakukan wawancara terhadap responden dan narasumber yaitu Pakar Hukum Tata Negara Dr. Nanik Prasetyoningsih dan Dr. King Faisal Sulaiman dan beberapa mantan calon hakim konstitusi seperti Prof. Dr. Ni'matul Huda, Prof. Dr. Aidul Fitriciada, Dr. Refly Harun, dan David Hartadi Tenggara selaku tenaga ahli DPR Komisi III. Selain itu juga dilakukan Focus Group Discussion (FGD) yang menghadirkan stakeholders terkait.

Analisis data dalam penelitian ini menggunakan deskriptif kualitatif. Pendekatan ini dilakukan dengan memperlakukan objek berdasarkan kategori tertentu, seleksi dan diklasifikasikan secara yuridis dan sistematis. Tahapan analisis data, yaitu: (1) data disistematisasi atau ditata dan disesuaikan dengan objek yang diteliti; (2) data yang telah disistematisasi, kemudian diuraikan dan dijelaskan sesuai objek yang diteliti berdasarkan teori; (3) data yang telah diuraikan kemudian dievaluasi, dinilai dengan menggunakan ukuran hukum yang berlaku. Pada tahap ini dilakukan beberapa aktivitas dilakukan seperti halnya mengumpulkan berbagai putusan dan literatur lainnya, pemetaan hasil interview. (4) Langkah tersebut dilakukan untuk memahami dan merumuskan hasil penelitian dan rekomendasi kebijakan secara mendalam dan komprehensif.

\section{PEMBAHASAN}

\section{Lembaga Peradilan yang Independen, Imparsial dan Hakim Berintegritas}

Lembaga peradilan merupakan aktor penting dalam menyehatkan praktik pemerintahan, khususnya bagi yang percaya bahwa itu bagian hak rakyat yang diatur oleh pemerintah. Inti lembaga peradilan adalah hakim memegang peran yang sentral dalam proses peradilan, sehingga hanya hakim yang baik yang dapat diharapkan memutus perkara yang mencerminkan rasa keadilan masyarakat, yakni yang sesuai dengan hukum. ${ }^{9}$ Hakim adalah harapan terakhir para justiabelen (pencari keadilan) dan oleh karena itu mereka harus membaca jiwa yang terkandung di dalam teks-teks hukum sebagaimana dipopulerkan oleh Ronald Dworkin (moral reading of law). ${ }^{10}$ Piagam internasional di bidang hak-hak sipil dan politik (ICCPR) mewajibkan adanya lembaga peradilan yang independen, imparsial dan kompeten dalam menjamin hakhak sipil dan politik warga negara ${ }^{11}$. Lembaga peradilan harus independen dalam menjalankan kewajibannya dalam rangka menjamin Hakim-hakim haruslah orang yang mampu bersikap adil dan independen dalam menjalankan kewajibannya dalam rangka menjamin kebebasan dan hak-hak individu dari ancama tirani kekuasaan. Bagi

\footnotetext{
${ }^{9}$ Rifqi Sjarief Asegaf, Hanya Hakim yang Bersih dan Kompeten yang Layak Adili Koruptor, Jurnal Kriminologi Indonesia, 2002, Vol.2 No.1, hlm. 9.

${ }^{10}$ Feri Amsari, Satjipto Rahardjo dalam Jagat Ketertiban Hukum Progresif, Jurnal Konstitusi, 2009, Vol.6 No.2, hlm. 182.

${ }^{11}$ Farid Suffian Shuaib, Malaysian Judicial Appointment Process: An Overview of Reform, Journal of Applied Sciences Research, 2011, Vol.7 No.13, hlm. 2273.
} 
masyarakat, memiliki peradilan yang imparsial sangat penting karena peradilan adalah harapan masyarakat yang tidak punya harapan dan tidak punya suara ${ }^{12}$.

Montreal Universal Declaration on the Independence of Justice (1983) memberi pengertian, "Seorang hakim harus bebas, dan menjadi kewajibannya untuk memutuskan perkara yang dihadapi secara imparsial, berdasarkan penilaiannya terhadap fakta dan pemahamannya terhadap hukum, tanpa batasan, pengaruh, bujukan, tekanan, ancaman, atau intervensi langsung, dari pihak manapun atau untuk alasan apapun. UN Basic Principles of the Independence of Judiciary (1985) memberi penafsiran mengenai independensi peradilan, "Kekuasaan kehakiman harus memutuskan perkara yang dihadapinya secara tidak memihak, berdasarkan fakta dan menurut hukum, tanpa batasan, pengaruh, bujukan, tekanan, ancaman, atau intervensi, langsung atau tidak langsung, dari pihak manapun atau untuk alasan apapun."

The Bangalore Principles of Judicial Conduct (2002), memberi penafsirannya mengenai independensi peradilan, "Independensi kekuasaan kehakiman merupakan hal yang diwajibkan untuk tegaknya rule of law dan suatu jaminan mendasar terhadap peradilan yang jujur. Seorang hakim harus mempertahankan dan menunjukkan independensi kekuasaan kehakiman baik secara individual maupun aspek institusional".

Dalam perkembangannya lembaga peradilan dan hakim paling tidak harus memenuhi beberapa syarat, yakni: independensi, imparsialitas, dan integritas. Pertama, independensi. Independensi hakim agung dan konstitusi merupakan prasyarat pokok bagi terwujudnya cita negara hukum, dan merupakan jaminan bagi tegaknya hukum dan keadilan. Prinsip ini melekat sangat dalam dan harus tercermin dalam proses pemeriksaan dan pengambilan keputusan atas setiap perkara, dan terkait erat dengan independensi MK sebagai institusi peradilan yang berwibawa, bermartabat, dan terpercaya. Independensi hakim dan pengadilan terwujud dalam kemandirian dan kemerdekaan hakim, baik sendiri-sendiri maupun sebagai institusi dari pelbagai pengaruh, yang berasal dari luar diri hakim berupa intervensi yang bersifat memengaruhi secara langsung atau tidak langsung berupa bujuk rayu, tekanan, paksaan, ancaman, atau tindakan balasan karena kepentingan politik, atau ekonomi tertentu dari pemerintah atau kekuatan politik yang berkuasa, kelompok atau golongan tertentu, dengan imbalan atau janji imbalan berupa keuntungan jabatan, keuntungan ekonomi, atau bentuk lainnya. Hal ini dapat menimbulkan tekanan terhadap lembaga peradilan yang seharusnya bersifat independen dan netral dalam menjalankan tugasnya. ${ }^{13}$

Kedua, imparsialitas. Ketakberpihakan (imparsialitas) merupakan prinsip yang melekat dalam hakikat fungsi hakim konstitusi sebagai pihak yang diharapkan memberikan pemecahan terhadap setiap perkara yang diajukan ke MK. Ketakberpihakan mencakup sikap netral, disertai penghayatan yang mendalam akan pentingnya keseimbangan antar kepentingan yang terkait dengan perkara. Prinsip ini melekat dan harus tercermin dalam tahapan proses pemeriksaan perkara sampai kepada tahap

\footnotetext{
${ }^{12}$ Ibid

${ }^{13}$ Lihat Brandon L. Bartels dan Christopher D. Johmston, 2020, Curbing the Court: Why the Public Constraints Judicial Independence, Cambridge University Press, Cambridge, hlm. 4
} 
pengambilan keputusan, sehingga putusan MK dapat benar-benar diterima sebagai solusi hukum yang adil bagi semua pihak yang berperkara dan oleh masyarakat luas pada umumnya.

Ketiga, integritas. Integritas merupakan sikap batin yang mencerminkan keutuhan dan keseimbangan kepribadian setiap hakim konstitusi sebagai pribadi dan sebagai pejabat negara dalam menjalankan tugas jabatannya. Keutuhan kepribadian mencakup sikap jujur, setia, dan tulus dalam menjalankan tugas profesionalnya, disertaiketangguhan batin untuk menepis dan menolak segala bujukrayu, godaan jabatan, kekayaan, popularitas, ataupun godaan-godaan lainnya. Sedangkan keseimbangan kepribadian mencakup keseimbangan ruhaniyah, dan jasmaniyah, atau mental dan fisik, serta keseimbangan antara kecerdasan spiritual, kecerdasan emosional, dan kecerdasan intelektual dalam pelaksanaan tugasnya. ${ }^{14}$ Selain dari itu, manifestasi dari kemandirian hakim juga harus mampu melawan pengaruh internal maupun eksternal dalam memutus sebuah perkara, dan haruslah berdasarkan preferensi hakim itu sendiri, dan interpretasi yang terhindar dari segala bentuk pengaruh, baik secara politik maupun ekonomi. ${ }^{15}$

\section{Mekanisme Seleksi Hakim Konstitusi}

Jabatan hakim di satu sisi merupakan jabatan yang sangat mulia, dan di sisi lain, jika tidak hati-hati, dapat merendahkan martabatnya karena banyak godaan yang siap menjerumuskannya. Sebagaimana diketahui jabatan Hakim boleh dikatakan merupakan jabatan yang dekat sekali dengan godaan-godaan duniawi. Betapa tidak, di tangan seorang hakim nasib dan masa depan seseorang akan ditentukan. Orang yang tadinya kaya raya dan terkenal sebagai donator di lingkungannya misalnya, tiba-tiba jatuh martabatnya sebagai manusia karena masuk penjara akibat putusan hakim. Oleh karena itu sudah menjadi suatu pandangan umum apabila orang yang berurusan dengan pengadilan akan berusaha semaksimal mungkin, dengan segala cara (baca menghalalkan segala cara) melakukan segala hal asalkan putusan hakim dapat berpihak kepadanya. ${ }^{16}$

Hakim konstitusi sebagai pemegang pedang keadilan, pengawal konstitusi, dan penjaga demokrasi, di tangannyalah keadilan dapat terwujud dan di tangannya pula keadilan akan hancur. Hakim adalah penegak hukum dan keadilan di tengah ketidakpercayaan sebagian masyarakat Indonesia terhadap kinerja kekuasaan Kehakiman. Berbagai kasus dan penyelesaian sengketa yang berlarut-larut menjadi halangan bagi kekuasaan kehakiman untuk menempatkan dirinya sebagai agen perubahan, ${ }^{17}$ bahkan diperparah dengan adanya judicial corruption (mafia peradilan) yang sudah mengakar dan sistemik yang dimainkan oleh para aktor, yang salah satunya adalah hakim.

Untuk memperbaiki berbagai persoalan sistem rekrutmen dan rendahnya integritas beberapa hakim diperlukan telaah syarat hakim dan sistem seleksi, yaitu:

\footnotetext{
${ }^{14}$ Lihat Louraine C. Arkfeld, 2007, The Rule of Law and an Independent Judiciary, Judges Journal, Vol.46 No.4 hlm. 12

${ }^{15}$ Lihat Aylin Aydin, 2013, Judicial Independence Across Democratic Regimes: Understanding the Varying Impact of Political Competition, Law and Society ReviewVol.47, hlm. 108

${ }^{16}$ Taufiqurrohman Syahuri, 2010, Problematika Tugas Konstitusional Komisi Yudisial, Jurnal Konstitusi, Vol.7 No.4, hlm. 49.

${ }_{17}$ Puguh Windarawan, 2012, Pergeseran Kekuasaan Tipologi Ketiga: Fenomena Kekuasaan Kearah Constitusional Heavy, Jurnal Konstitusi, Vol.9 No.4, hlm. 625.
} 
Pertama, syarat hakim konstitusi. Syarat hakim konstitusi diatur dalam UUD 1945 dan Undang-undang MK. Pasal 24C ayat (5) UUD 1945 mengatur, "Hakim konstitusi harus memiliki integritas dan kepribadian yang tidak tercela, adil, negarawan yang menguasai konstitusi dan ketatanegaraan, serta tidak merangkap sebagai pejabat negara." Berdasarkan pasal-pasal di atas dapat dijabarkan beberapa syarat yang berkaitan dengan independensi, imparsialitas dan integritas, yaitu:

a. Syarat bertakwa kepada Tuhan Yang Maha Esa. Syarat bertakwa kepada Tuhan Yang Maha Esa bagi hakim agung dan konstitusi adalah syarat multak di negara Indonesia sebagainegarabangsayangreligius,yangdalampraktekkehidupannyatidakmemisahkan nilai, asas/ prinsip, norma/ kaidah dan sikap tidak yang bersumber pada agama dan eksistensi negara. Bertakwa berarti menjalankan ajaran agama sebagai manusia Pancasila yang seutuhnya. Sila Ketuhanan Yang Maha Esa dalam kaitannya dengan tertib hukum berimplikasi bahwa peraturan perundang-undang harus mengandung nilai-nilai Ketuhanan Yang Maha Esa yang terkandung dalam agama sebagai nilai materialnya, dan semua hukum positif harus diukur sesuai aturan yang berasal dari Tuhan. ${ }^{18}$ Calon hakim konstitusi yang tidak memenuhi syarat ini, jangan diloloskan, misalnya mendukung gerakan seks bebas dengan alasan hak asasi manusi.

b. Syarat Integritas. Integritas merupakan sikap batin yang mencerminkan keutuhan dan keseimbangan kepribadian setiap hakim konstitusi sebagai pribadi dan sebagai pejabat negara dalam menjalankan tugas jabatannya. Jika merujuk pada kode etik hakim konstitusi, apa yang telah dilakukan oleh Hakim Konstitusi Akil Mochtar, Hakim Konstitusi Patrialis Akbar, Hakim Arief Hidayat adalah tindakan yang tidak berintegritas/tidak bermoral. Karena Akil Mochtar dan Patrialis akbar terbukti telah memanfaatkan kekuasaannya untuk menerima suap yang menguntungkannya dan mencoba mempengaruhi keputusan politik pejabat negara lainnya, dan sementara itu, Hakim Arief Hidayat terbukti melakukan pelanggaran kode etik ringan dalam bentuk memengaruhi keputusan pejabat.

c. Syarat berakhlak mulia. Orang yang memiliki akhlak mulia itu adalah orang yang mampu mengintegrasikan tentang hubungannya dengan Tuhan dan hubungannya dengan masyarakat (dengan keseluruhan jiwa dan raganya). Jika ibadahnya baik, maka muamalahnya juga harus baik.

d. Syarat kepribadian tidak tercela. Syarat ini bersifat multi tafsir adalah perbuatan tidak tercela, perbuatan tidak tercela tidak memiliki tolok ukur yang jelas, misalnya apakahpelecehanseksualmerupakan perbuatan tidak tercela?Kepribadian tidak tercela tidak hanya dalam bentuk tindakan hukum/ sikap, tetapi juga pemikiran hukum yang menyimpang dari nilai-nilai Pancasila dan UUD 1945. Pemikiran ahli hukum yang mendukung seks bebas, gay, lesbian dll bertentangan dengan hak asasi manusia sesuai dengan nilai-nilai Pancasila.

e. Syarat Adil. Dimensi moralitas syarat "adil". Adil bermakna menempatkan sesuatu pada tempatnya dan memberikan yang menjadi haknya, yang didasarkan pada suatu

\footnotetext{
${ }^{18}$ Kaelan, 2002, Pendidikan Pancasila, Paradigma, Yogyakarta, hlm. 99
} 
prinsip bahwa semua orang sama kedudukannya di depan hukum. Dengan demikian, tuntutanyangpalingmendasardarikeadilanadalahmemberikanperlakuandanmemberi kesempatan yang sama (equality and fairness) terhadap setiap orang. Oleh karenanya, seseorang yang melaksanakan tugas atau profesi di bidang peradilan yang memikul tanggung jawab menegakkan hukum yang adil dan benar harus selalu berlaku adil dengan tidak membeda-bedakan orang. Pasal 24 ayat (1) mengatur ketentuan bahwa "Kekuasaankehakimanmerupakankekuasaanyangmerdekauntukmenyelenggarakan peradilan guna menegakkan hukum dan keadilan", makna hukum dapat ditemukan dalam teks/pasal dalam peraturan perundang-undangan, sementara makna keadilan dapatditemukandalamteksmaupunnilai/asas/normayanghidupditengahmasyarakat.

f. Syarat negarawan. Syarat negarawan hanya untuk hakim konstitusi, negarawan merupakan orang yang sudah tidak lagi mengutamakan dirinya. Jadi ketika menjadi hakim konstitusi tidak lagi mengutamakan kepentingan kelompok, golongan maupun kepentingan bisnis.

g. Syarat menguasai konstitusi dan ketatanegaraan.

Syarat ini merupakan syarat hakim konstitusi, Hakim konstitusi harus memahami UUD 1945 dalam konteks keseluruhan jiwa (spirit) yang terkandung di dalamnya guna membangun kehidupan ketatanegaraan yang lebih tepat dalam upaya mencapai cita negara (staat-idee) yaitu mewujudkan negara hukum demokratis dan negara demokrasi berdasarkan hukum yang merupakan penjabaran dari pokok pikiran yang terkandung dalam Pembukaan UUD 1945. ${ }^{19}$ Tidak hanya menguasai Konstitusi atau UUD 1945 , tetapi juga perkembangan nilai-nilai konstitusi yang sesuai Pancasila dan the living constitution dan mendukung komunisme bukan bekas anggota organisasi terlarang partai Komunis, Indonesia, termasuk organisasi massanya, atau bukan orang yang terlibat langsung dalam G.3O.S/PKI.

h. Syarat tidak merangkap sebagai pejabat negara. Calon hakim konstitusi tidak boleh merangkap jabatan, hal ini akan menimbulkan konflik kepentingan antar jabatan. Dalamkonteksmoralitas demokrasi, tidakbaik menjadipejabat publikpadadualembaga secara bersamaan, konteks ini menunjukkan keserakahan demokrasi dalam jabatan publik dan menyebabkan kurang amanah.

i. Syarat mampu secara rohani. Kemampuan secara rohani berarti sehat jiwanya, sehat moralnya, baik perilakunya di tengah masyarakat. Kesehatan rohani ini tidak hanya didasarkan pada tes kesehatan jiwa, namun perlu adanya track record kesehatan jiwa calon hakim tersebut di masyarakat. Misalnya calon hakim konstitusi di masyarakat memiliki perilaku angkuh dan suka merendahkan orang lain, berarti kondisi ini tidak sehat rohaninya.

j. Syarat tidak pernah dijatuhi pidana penjara berdasarkan putusan pengadilan yang telah memperoleh kekuatan hukum tetap. Syarat ini sebagai bukti bahwa calon hakim konstitusi harus bersih dari perbuatan pidana pada masa lalu.

${ }^{19}$ Tanto Lailam, 2014, Penafsiran Konstitusi dalam Pengujian Konstitusionalitas Undang-Undang terhadap Undang-Undang Dasar, Jurnal Media Hukum, Vol.21 No.1, hlm. 103 
k. Syarat tidak merangkap sebagai pengusaha dan tidak sedang dinyatakan pailit berdasarkan putusan pengadilan.

1. Syarattidakmerangkap sebagai anggota partai politik, tidak merangkap sebagaiadvokat, dan tidak merangkap sebagai pegawai negeri.

Jika diperhatikan syarat di atas, maka dapat digarisbawahi bahwa secara peraturan perundang-undangan, Indonesia memiliki syarat pengangkatan hakim konstitusi yang sangat baik. Persoalannya adalah bagaimana membangun mekanisme seleksi yang baik agar mendapatkan orang-orang dengan syarat di atas dengan kualifikasi terbaik. Di tingkat inilah, maka mekanisme seleksi yang ada sekarang menjadi penting untuk dievaluasi.

Kedua, mekanisme seleksi hakim konstitusi. Masalah pengangkatan hakim, dalam hal ini hakim konstitusi menjadi sangat penting untuk terus dievaluasi karena hakim-hakim konstitusi merupakan hakim di level tertinggi dalam sistem peradilan. Pengangkatan hakim lazimnya secara luas diartikan sebagai cara bagaimana hakim tersebut direkrut. ${ }^{20}$ Masalahnya, pengangkatan hakim konstitusi yang diusulkan oleh MA saat ini bersifat tertutup dan hanya mengusulkan calon dari internal MA dan Peradilan di bawahnya. Seharusnya metode rekrutmen hakim MK yang diusulkan oleh MA terbuka untuk umum, bukan hanya untuk internal hakim di lingkungan MA, namun juga orang yang di luar lembaga kehakiman selama dia memenuhi syarat sebagaimana diatur dalam UUMK. ${ }^{21}$ Sistem ini merupakan sistem yang dibangun pasca reformasi politik yang salah salah satu agendanya adalah adanya reformasi penegakan hukum. Untuk hakim konstitusi ada lembaga negara yang berwenang mengusulkan pengangkatan hakim konstitusi yaitu 3 dari Presiden, 3 orang dari Dewan Perwakilan Rakyat (DPR) dan 3 orang dari Mahkamah Agung (MA). Model pengangkatan hakim konstitusi seperti ini juga dianut di Korea Selatan.

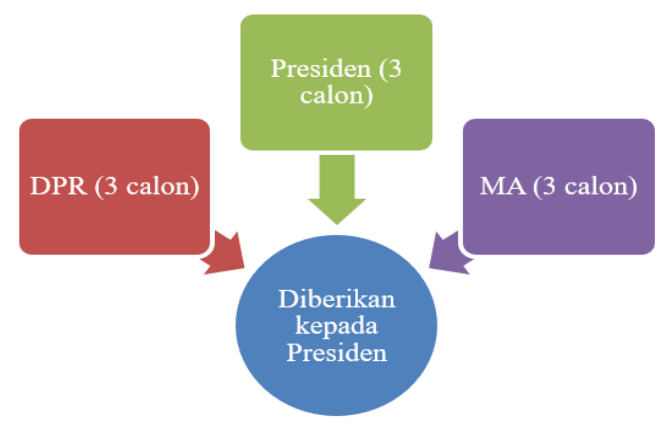

Gambar 1. Kewenangan Pengangkatan Hakim MK

Model pengangkatan hakim konstitusi di atas cukup menggambarkan bahwa proses pengangkatan hakim akan selalu diwarnai oleh upaya dominasi pengangkatan hakim oleh pihak eksekutif dan legislatif karena kasus-kasus yang melibatkan lembaga

${ }^{20}$ Samuel Spac, 2018, Recruiting of European Judges in the Age of Judicial Self-Government, Gerrman Law Journal, Vol.19 No.5, hlm. 2078-2104.

${ }^{21}$ Lihat Andi Saputra, 2016, Tanpa Seleksi yang Transparan, Hakim Konstitusi Anwar Usman Dipertanyakan, https:// news.detik.com/berita/d-3182850/tanpa-seleksi-yang-transparan-hakim-konstitusi-anwar-usman-dipertanyakan diakses pada 18 Maret 2021. 
pemerintahan yang berujung pada kekuasaan puncak eksekutif dan legislatif itu sendiri, di mana mereka biasanya berkoalisi dan memiliki kekuatan mayoritas di pemerintahan. Dalam proses fit and proper test yang dilakukan di lembaga legislatif, di sinilah terjadi kemungkinan adanya gangguan terhadap independensi hakim konstitusi. Pada proses ini sangat tergantung pada sikap kenegarawanan anggota DPR dan Presiden. ${ }^{22}$ Jika politisi di DPR dan Presiden mampu meletakkan dirinya sebagai negarawan, makanya proses seleksi akan less political atau kurang dicampuri oleh kepentingan politik jangka pendek.

Hal ini terbukti campur tangan kepentingan politik dari proses seleksi mantan Hakim MK Akil Mochtar, Patrialis Akbar, dan Arief Hidayat. Ketiga mantan Hakim MK tersebut berasal dari lembaga politik, yaitu Presiden dan DPR. ${ }^{23}$ Pada proses seleksi hakim Akil Mochtar, proses politik sangat terasa pada proses tersebut. Sebagai anggota DPR RI Fraksi Golongan Karya (Golkar), Akil Mochtar terpilih bersama dengan Mahfud MD dan Jimly Asshiddiqie pada periode pertamanya menjabat sebagai hakim MK. Namun pada periode kedua, Akil Mochtar langsung terpilih tanpa melalui proses fit and proper test, namun melalui mekanisme singkat dan politik yang diusulkan dan dipilih oleh lembaga DPR. ${ }^{24}$

Selanjutnya, pemilihan hakim Patrialis Akbar yang sangat kontroversi. Proses pemilihan hakim Patrialis Akbar dipilih tanpa melalui proses yang transparan dan melanggar Pasal 19 UUMK. ${ }^{25}$ Patrialis Akbar yang diusulkan oleh Presiden merupakan kader aktif dari Partai Amanat Nasional, sehingga memunculkan kritik dari masyarakat mengenai kredibilitas dan kualitas dari Patrialis Akbar.

Terakhir adalah proses rekrutmen hakim Arief Hidayat pada periode kedua yang sangat kontroversial. Setelah mendapatkan beberapa kali pelanggaran etik berdasarkan putusan Dewan Etik MK, Arief Hidayat tetap mulus menjadi hakim MK pada periode keduanya. Dimana Arief Hidayat diusulkan oleh lembaga DPR. Proses terpilihnya Arief Hidayat sebagai hakim MK dilalui tanpa adanya proses seleksi yang jelas, transparan, akuntabel, dan etika bernegara. ${ }^{26}$ Terbukti, proses tersebut mendapatkan kembali teguran lisan dari Dewan Etik karena terbukti bertemu dengan anggota Komisi III DPR RI.

Hal ini juga terjadi pada internal diri Mahkamah Agung ketika akan mencalonkan tiga kandidatnya yang berasal dari lembaga tersebut. Khusus MA, proses pencalonan yang dilakukan cenderung tertutup, dan tidak jarang pula hakim yang disodorkan tidak sesuai dengan kompetensi yang dibutuhkan oleh Mahkamah Konstitusi. ${ }^{27}$ Di

\footnotetext{
${ }^{22}$ Lihat Clyde D. Compton, 2005, An Independent Judiciary, Res Gestae, Vol.49 No.5, hlm. 5

${ }^{23}$ Lihat Indramayu, Jayus, dan Rosita Indrayati, Rekonseptualisasi Seleksi Hakim Konstitusi sebagai Upaya Mewujudkan Hakim Konstitusi yang Berkualifikasi, Lentera Hukum, 2017, Vol.4 No.1, hlm.10

${ }^{24}$ Lihat Winda Wijayanti, Nuzul Quraini M, Siswantana Putri R, Transparansi dan Partisipasi Publik dalam Rekrutmen Calon Hakim Konstitusi, Jurnal Konstitusi, 2015, Vol.12, No.4, hlm.674

${ }_{25}$ Syamsuddin Radjab, 2017, Cacat Hukum Pemilihan Hakim Konstitusi, https://antikorupsi.org/id/article/cacat-hukum-pemilihan-hakim-konstitusi, diakses pada 18 Maret 2021

${ }^{26}$ ibid

${ }^{27}$ Interview dengan salah satu hakim Agung RI pada tanggal 25 Oktober 2019. Hakim Agung ini menyebutkan bahwa dalam beberapa kasus, hakim yang diajukan oleh MA ke MK adalah hakim dengan latar belakang Hukum Perdata sehingga tidak sesuai dengan syarat kompetensi yang seharusnya diperhatikan oleh MA.
} 
samping itu, proses seleksi hakim MA tidak memilki kejelasan aturan sebenarnya yang memiliki kewenangan untuk memutuskan calon yang akan diangkat. Apakah menjadi kewenangan Ketua MA atau menjadi kewenangan Pimpinan MA secara kolegial. Hal ini akan berdampak pada akuntabilitas hakim terkait dalam menjalankan tugasnya. Ketika lembaga peradilan dalam menyeleksi hakimnya tidak memiliki standar dan tertutup, maka sesungguhnya kredibilitas dan akuntabilitas dari lembaga tersebut tidak ada. ${ }^{28}$

Pada prinsipnya, judicial independence dan accountable adalah hal yang berbeda dan memiliki perlakuan yang berbeda pula. ${ }^{29}$ Selain itu, proses tertutup akan sulit menjamin independensi hakim nantinya, ${ }^{30}$ karena keterlibatan publik sangat kecil dan bahkan tidak ada. Oleh karena itulah, bagaimana membangun model pengangkatan hakim yang menjamin lahirnya hakim konstitusi yang independen dan akuntabel menjadi sangat krusial. Berikut di bawah ini adalah mekanisme seleksi hakim MK di tiga lembaga negara. ${ }^{31}$

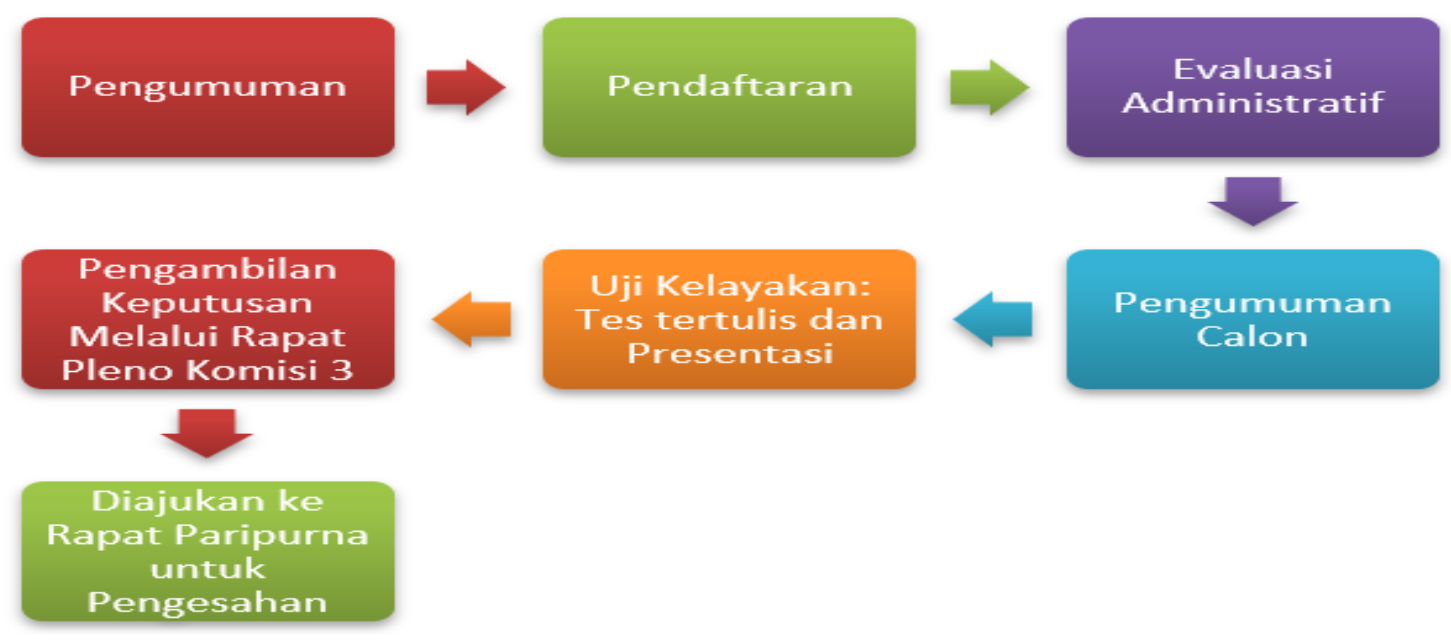

Gambar 2. Mekanisme seleksi hakim MK di DPR

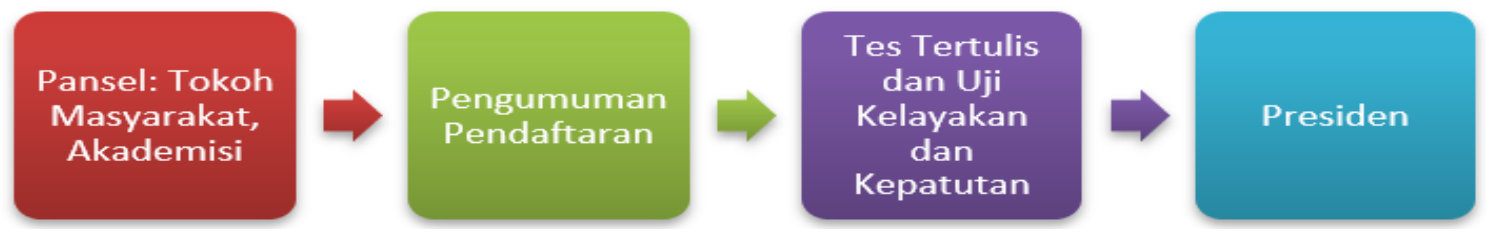

Gambar 3. Mekanisme seleksi hakim MK oleh Presiden

\footnotetext{
${ }^{28}$ Lihat Cora Hoexter, (2018), The Judicial Service Commission: Lessons from South Africa dalam Graham Gee and Erika Rackley (ed), Debating Judicial Appointments in an Age of Diversity, Routledge, London, hlm. 83

${ }^{29}$ Stephen B. Burbank, 2013, What Do We Mean by "Judicial Independence"?, Ohio State Law Journal, Vol.64, hlm. 332

${ }^{30}$ Shirley S. Abrahamson, Judicial Independence as A Campaign Platform the Importance of Fair and Impartial Courts, Michigan Bar Journal, 2005, Vol.84, hlm.41.

${ }^{31}$ Hasil wawancara dengan David Hartadi Tenggara pada tanggal 25 Oktober 2019.
} 


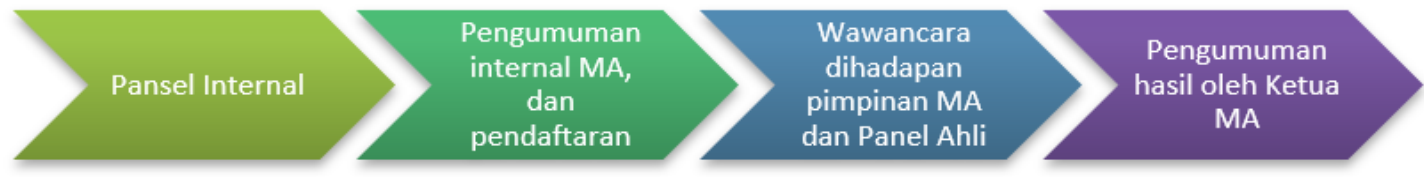

Gambar 4. Mekanisme seleksi hakim MK oleh MA

\section{Implikasi Sistem Seleksi terhadap Independensi Peradilan}

Banyak ahli yang berpendapat bahwa salah satu ciri dari independensi peradilan dapat dilihat dari bagaimana proses seleksi hakim pada lembaga tersebut. ${ }^{32}$ Selanjutnya Independensi peradilan dibagi menjadi dua tipe, yaitu berdasarkan independensi yang melekat pada nilai institusi (the institutional-type definition of judicial independence), dan tipe kedua yaitu yang melekat kepada pola dan tingkah laku para hakim (performancebased definition of judicial independence) di lembaga peradilan. ${ }^{33}$ Selain daripada itu, wajah peradilan ditunjukan oleh para hakim, sejauh mana dia bisa netral, berintegritas, dan memiliki sifat yang bijaksana dalam memutus perkara. Apabila sudah terjadi penyimpangan dan pelanggaran etik dan/atau pidana, maka sesungguhnya akan meruntuhkan kepercayaan kepada institusi peradilan secara melekat. ${ }^{34}$ Hal tersebut juga menjadikan alasan yang mendasar sebagai faktor yang mendorong perkembangan hukum agar lebih maju dan lebih baik. ${ }^{35}$

Di bawah ini akan diuraikan dan dianalisis beberapa kasus yang dianggap terkait independensi, imparsialitas dan integritas hakim Konstitusi. Adapun kasus-kasus yang akan diulas adalah Putusan MK No. 1-2/PUU-XII/2014, putusan No.81/PUU-IX/2011, dan beberapa kasus suap dan pelanggaran kode etik yang melibatkan hakim konstitusi.

\section{a. Pelanggaran Prinsip Imparsialitas Hakim.}

Putusan MK No.1-2/PUU-XII/2014 perihal Pengujian Undang-undang No.4 Tahun 2014 tentang Penetapan Peraturan Pemerintah Pengganti Undang-undang No.1 Tahun 2013 tentang Perubahan Kedua Atas Undang-undang No.24 Tahun 2003 tentang MK menjadi Undang-undang (selanjutnya disebut UU MK Perubahan Kedua No.4/ 2014), ${ }^{36}$ yang justru menambah deret ketidakpercayaan publik terhadap lembaga MK. Lahirnya Perppu ini sebenarnya layak untuk diapresiasi, karena Perppu MK dikeluarkan oleh Pemerintah dimaksudkan untuk mengembalikan kepercayaan publik terhadap MK akibat adanya kemerosotan integritas dan kepribadian salah satu hakim

\footnotetext{
${ }^{32}$ Lihat Lydia Brashear Tiede, Judicial Independence: Often Cited, Rarely Understood, Journal of Coontemporary Legal Issues, 2006, Vol.15, hlm. 136

${ }^{33}$ Lihat Brian K. Landsberg, The Role of Judicial Independence, Pacific McGeorge Global Bussiness \& Development Law Journal, 2007, Vol.19 No.2, hlm. 331-332

${ }^{34}$ Terri Peretti, A Normative Appraisal of Social Scientific Knowledge Regarding Judicial Independence, Ohio State Law Journal, 2003, Vol.64, hlm. 365

${ }^{35}$ Lihat Daniel M. Klerman, Legal Infrastructure, Judicial Independence, and Economic Development, Pacific McGeorge Global Bussiness \& Development Law Journal, 2007, Vol.19 No.2, hlm. 428

${ }^{36}$ Lihat Putusan MK No.1-2/PUU-XII/2014 Perihal Pengujian Undang-Undang No.4 Tahun 2014 Tentang Penetapan Peraturan Pemerintah Pengganti Undang-Undang No.1 Tahun 2013 Tentang Perubahan Kedua Atas Undang-Undang No.24 Tahun 2003 Tentang Mahkamah Konstitusi Menjadi Undang-Undang.
} 
konstitusi AM (mantan Ketua MK) yang terjaring 'operasi tangkap tangan' oleh KPK karena menerima suap dari pihak yang sedang berperkara di MK. Ini merupakan bukti nyata adanya judicial corruption yang dilakukan oleh hakim konstitusi. Kasus tersebut menimbulkan 'kegaduhan politik', kesedihan luar biasa, runtuhnya kepercayaan publik terhadap MK, serta menghancurkan kredibilitas dan legitimasi putusan-putusan yang telah dikeluarkan MK selama ini. ${ }^{37}$

Namun, substansi yang diatur dalam undang-undang tersebut yang menurut para Pemohon dianggap telah bertentangan dengan UUD 1945 pada pokoknya menyangkut tiga hal utama, yaitu: (1) penambahan persyaratan untuk menjadi hakim konstitusi; (2) memperjelas mekanisme proses seleksi dan pengajuan hakim konstitusi; dan (3) perbaikan sistem pengawasan hakim konstitusi. Dalam hal ini penulis hanya menguraikan salah satu Pasal yang dinyatakan bertentangan dengan UUD 1945.

Pertama, dalam undang-undang ini sistem seleksi hakim konstitusi mengalami pergeseran, dalam undang-undang ini sistem seleksi hakim konstitusi melibatkan Komisi Yudisial. Namun oleh Putusan MK No.1-2/PUU-XII/2014, ketentuan tersebut dibatalkan. Dalam pertimbangannya disebutkan bahwa Undang-Undang yang mengatur pengajuan calon Hakim Konstitusi melalui Panel Ahli yang dibentuk oleh Komisi Yudisial - walaupun 3 (tiga) dari 7 (tujuh) orang anggotanya masing-masing ditunjuk oleh Mahkamah Agung, DPR, dan Presiden - telah nyata-nyata mereduksi kewenangan konstitusional Mahkamah Agung, DPR, dan Presiden.

Selain itu, pelibatan Komisi Yudisial sebagaimana ketentuan dalam UU 4/2014 adalah merupakan bentuk penyelundupan hukum karena hal tersebut secara jelas bertentangan dengan Putusan Mahkamah Nomor 005/PUU-IV/2006, tanggal 23 Agustus 2006, yang menegaskan secara konstitusional bahwa Hakim Mahkamah Konstitusi tidak terkait dengan Komisi Yudisial yang mendapatkan kewenangan berdasarkan Pasal 24B UUD 1945. Terhadap tindakan penyelundupan hukum yang demikian maupun tindakan yang inkonstitusional lainnya harus dikoreksi oleh Mahkamah melalui upaya judicial review ini demi menjaga tegaknya konstitusi.

Kedua, syarat keterlibatan dalam partai politik. Norma hukum yang dipersoalkan dalam sub kajian ini adalah Pasal 15 ayat (2) huruf i UU MK Perubahan Kedua No.4/2014 yang mengatur bahwa Hakim konstitusi harus memenuhi syarat "tidak menjadi anggota partai politik dalam jangka waktu paling singkat 7 (tujuh) tahun sebelum diajukan sebagai calon hakim konstitusi" sebagai syarat Hakim Konstitusi yang dinilai oleh pemohon bertentangan dengan UUD 1945. Norma hukum ini dilatarbelakangi fakta: (1) tertangkap tangannya M. Akil Mochtar (yang waktu itu sebagai Ketua MK) oleh KPK, (2) M. Akil Mochtar merupakan politisi yang menjadi Hakim Konstitusi, (3) adanya penilaian pembentuk Perpu terkait generalisasi bahwa semua politisi berakhlak seperti M. Akil Mochtar.

${ }^{37}$ Ni'matul Huda, Problematika Substantif Perppu Nomor 1 Tahun 2013 Tentang Mahkamah Konstitusi, Jurnal Konstitusi, 2013, Vol.10 No.4, hlm. 558-559

124 Jurnal IUS Kajian Hukum dan Keadilan 
Norma hukum ini dinyatakan bertentantangan dengan UUD 1945 dengan berbagai argumentasi hukum, meliputi:

Norma hukum Pasal 15 ayat (2) huruf i UU MK Perubahan Kedua No.4/2014 bertentangan dengan beberapa Pasal dalam UUD 1945. Norma hukum Pasal 15 ayat (2) huruf i UU MK Perubahan Kedua No.4/2014 bertentangan dengan beberapa Pasal dalam UUD 1945 yaitu: bertentangan dengan Pasal 24C ayat (3) yang menyatakan, "MK mempunyai 9 orang anggota hakim konstitusi yang ditetapkan oleh Presiden, yang diajukan masing-masing tiga orang oleh MA, tiga orang oleh Dewan Perwakilan Rakyat, dan tiga orang oleh Presiden"; bertentangan dengan Pasal 28 yang menyatakan, "Kemerdekaan berserikat dan berkumpul, mengeluarkan pikiran dengan lisan dan tulisan dan sebagainya ditetapkan dengan undang-undang"; bertentangan dengan Pasal 28D ayat (1), "Setiap orang berhak atas pengakuan, jaminan, perlindungan, dan kepastian hukum yang adil serta perlakuan yang sama di hadapan hukum"; bertentangan dengan Pasal 28D ayat ayat (3), "Setiap warga negara berhak memperoleh kesempatan yang sama dalam pemerintahan"; dan bertentangan dengan Pasal 28E ayat (3), "Setiap orang berhak atas kebebasan berserikat, berkumpul, dan mengeluarkan pendapat".

Dalam pengujian undang-undang ini, sikap kenegarawanan dan adil hakim konstitusi tidak tampak, namun yang tampak adalah sikap egosime para hakim MK yang "merasa dirinya adalah orang-orang yang adil dan jujur melebihi pejabat lembaga negara lainnya" dan tentunya secara tidak langsung putusan berpihak pada politisi dibandingkan kepentingan bangsa dan negara. Argumentasi yang dibangun MK tidak komprehensif dan solutif, serta cenderung terlihat kepentingan politis lebih kental dibandingkan kepentingan hukum. MK juga tidak menguraikan makna pertentangan norma hukum secara jelas, misalnya Pasal 15 ayat (2) huruf i bertentangan dengan Pasal 28D ayat ayat (3), "Setiap warga negara berhak memperoleh kesempatan yang sama dalam pemerintahan". Ketentuan Pasal a quo, "Hakim konstitusi harus memenuhi syarat tidak menjadi anggota partai politik dalam jangka waktu paling singkat 7 (tujuh) tahun sebelum diajukan sebagai calon hakim konstitusi" secara jelas tidak melarang politisi untuk menjadi hakim MK, tetapi memberikan tenggang waktu bagi hakim MK yang berasal dari politisi untuk bebas dari kepentingan partai politik. Hal ini bertujuan agar hakim MK terpilih memiliki independensi dan imparsialitas yang kokoh dalam menyelesaikan sengketa Pemilu yang salah satu pihaknya adalah partai politik.

Menurut Erhard Blankenburg bahwa independensi peradilan dapat diuji melalui dua hal, yaitu ketidakberpihakan (impartiality) dan keterputusan relasi dengan para partai politik (political insularity). Imparsialitas terlihat pada gagasan bahwa hakim akan mendasarkan pada hukum dan fakta-fakta di persidangan, bukan atas dasar keterkaitan dengan salah satu pihak yang berperkara. Imparsialitas proses peradilan hanya dapat dilakukan jika hakim dapat melepaskan diri dari konflik kepentingan atau faktor semangat pertemenan (collegial) dengan pihak yang berperkara. Karenanya, hakim harus mengundurkan diri dari proses persidangan jika ia melihat ada potensi 
imparsialitas. Sementara pemutusan relasi dengan dunia politik penting bagi seorang hakim agar ia tidak menjadi alat merealisasikan tujuan-tujuan politik. ${ }^{38}$

\section{b. Inkonsistensi Putusan Hakim}

Idealnya ketentuan mengenai tenggang waktu dalam pemilihan jabatan publik sebagai syarat untuk menciptakan lembaga negara yang lebih independen adalah hal yang wajar dan tidak bertentangan dengan UUD 1945. Berdasarkan Putusan MK No.81/PUU-IX/2011 perihal pengujian Undang-undang No.15 Tahun 2011 tentang Penyelenggara Pemilihan Umum, MK menilai, "tenggang waktu pengunduran diri dari partai politik, menurut MK adalah patut dan layak jika ditentukan sekurangkurangnya 5 (lima) tahun sebelum yang bersangkutan mengajukan diri sebagai calon anggota komisi pemilihan umum. Lima tahun dinilai patut dan layak oleh MK karena bertepatan dengan periodisasi tahapan pemilihan umum. Ketentuan 5 (lima) tahun juga diakomodasi oleh Undang-Undang Penyelenggara Pemilihan Umum sebelumnya, yaitu Undang-Undang No.22 Tahun 2007 tentang Penyelenggara Pemilihan Umum. Dengan demikian, MK berpendapat bahwa Pasal 11 huruf i dan Pasal 85 huruf i Undangundang Penyelenggaraan Pemilu No.15/2011, sepanjang frasa "mengundurkan diri dari keanggotaan partai politik ... pada saat mendaftar sebagai calon" bertentangan dengan Pasal 22E ayat (5) UUD 1945 sepanjang tidak dimaknai "sekurang-kurangnya dalam jangka waktu 5 (lima) tahun telah mengundurkan diri dari keanggotaan partai politik pada saat mendaftar sebagai calon". ${ }^{39}$

Jika dibandingkan maka terlihat sikap tidak adil hakim MK karena di satu sisi ketika hakim MK memutus syarat bagi lembaga lain (KPU) yang terbebas dari parpol selama 5 tahun sebelum mendaftar adalah patut dan layak, sementara syarat sebagai hakim konstitusi yang bebas dari parpol adalah tidak patut dan tidak layak sehingga dinyatakan bertentangan dengan UUD 1945. Dalam hal ini terbukti bahwa hakim MK lebih mengutamakan kepentingan pribadinya daripada kepentingan umum untuk mewujudkan lembaga MK yang lebih independen. Meskipun keberadaan hakim konstitusi melalui proses seleksi beberapa lembaga, akan tetapi tetap harus dijamin bahwa hakim konstitusi independen dari lembaga-lembaga tersebut. Dalam melaksanakan tugas dan kewenangannya, para hakim diharapkan bisa bertindak netral dan 'menjaga jarak' dengan lembaga yang mengusulkan. Tindakan itu diperlukan agar hakim dalam memeriksa perkara dan memberikan putusan, berlaku dan bersikap adil tanpa mudah dipengaruhi oleh kepentingan lembaga-lembaga lain. Demikian pula sebaliknya, lembaga-lembaga yang memiliki kewenangan konstitusional mengajukan

${ }^{38}$ A. Muhammad Asrun, 2004, Krisis Peradilan: Mahkamah Agung di bawah Suharto, Elsam, Jakarta, hlm. 307

${ }^{39}$ Putusan MK No.81/PUU-IX/2011 perihal pengujian Undang-Undang No.15 Tahun 2011 tentang Penyelenggara Pemilihan Umum, hlm.58 
hakim konstitusi, sedapat mungkin menahan diri untuk tidak memengaruhi hakim dalam proses penanganan perkara. ${ }^{40}$

Argumentasi MK dalam putusan No.81/PUU-IX/2011, apabila dari jumlah anggota KPU ada sebagian yang berasal dari partai politik, maka akan lebih mengancam kemandirian apabila wakil partai politik di KPU hanya terdiri dari beberapa partai politik peserta pemilu, sedangkan peserta pemilu terdiri dari banyak partai politik, sehingga menyebabkan pemilu berjalan tidak jujur dan tidak adil bagi sebagian partai politik peserta pemilu. Di samping itu, pada saat menentukan anggota KPU akan terjadi perebutan antara partai politik peserta pemilu yang mempunyai kepentingan politik terhadap pemilu. ${ }^{41}$ Anehnya, kenapa argumentasi tersebut tidak dijadikan alasan untuk memutus syarat hakim MK, malahan memberikan argumentasi yang berbeda. Apa bedanya lembaga pelaksana Pemilu dengan lembaga yang menyelesaikan sengketa pemilu, dua-duanya membutuhkan kemandirian, apalagi sudah nyata-nyata bahwa AM (mantan Ketua MK) justru tidak mandiri dan tidak jujur (terbukti dalam kasus tindak pidana penyuapan oleh para pihak yang berperkara).

Menurut Saldi Isra bahwa ketentuan "tidak menjadi anggota partai politik dalam jangka waktu paling singkat 7 (tujuh) tahun sebelum diajukan sebagai calon hakim konstitusi" jelas dimaksudkan agar hakim konstitusi diisi oleh orang-orang yang tidak terkait langsung dengan kewenangan MK untuk menangani sengketa hasil pemilihan umum, yang sangat terkait dengan kepentingan partai politik. Jika hakim konstitusi disesaki orang partai, tentu saja akan timbul keraguan soal obyektivitas penyelesaian sengketa dimaksud. Tambahan frasaini seharusnya dibaca sebagailangkah strategis untuk mencegah dominasi aktivis parpol menjadi hakim konstitusi. Dengan dibatalkannya syarat ini dalam waktu dekat, sangat mungkin mayoritas hakim konstitusi akan disesaki kalangan partai. Bahkan, suatu waktu nanti, jika ada sebuah partai menjadi kekuatan mayoritas (50 persen lebih) di DPR dan partai bersangkutan juga memegang posisi presiden, sangat mungkin enam hakim konstitusi akan berasal atau didukung dari partai sama. ${ }^{42}$ Sehingga Presiden akan mampu menentukan arah MK melalui dua jalur, baik jalur kepresidenan dan jalur jalur partai di DPR, ${ }^{43}$ dan bilamana itu benar-benar terjadi, sangat mungkin MK mengalami kelumpuhan. Karena itu, banyak kalangan sulit menerima ketika tak satu pun hakim konstitusi melakukan dissenting opinion dengan pembatalan syarat ini. Karena itu, membatalkan syarat tujuh tahun dengan menerobos asas nemo judex idoneus in propria causa adalah tindakan kebablasan. ${ }^{44}$

\footnotetext{
${ }^{40}$ KRHN, 2008, Menggapai Keadilan Konstitusi; Suatu Rekomendasi untuk Revisi UU Mahkamah Konstitusi, Konsorsium Reformasi Hukum Nasional (KRHN), Jakarta, hlm. 53

${ }^{41}$ Putusan MK No.81/PUU-IX/2011, Loc.Cit.

${ }^{42}$ Saldi Isra, Tim pakar dan Pengisian Hakim Konstitusi, diakses dari http://www.saldiisra.web.id/index.php? option=com_content\&view=article\&id=566:tim-pakar-a-pengisian-hakim-konstitusi tanggal 25 Juli 2020, lihat juga Saldi Isra, Selamatkan Jalan Hakim MK, diakses dari http://www.saldiisra.web.id/index.php?option=com content\&view $=$ article\&id=565: selamatkan-jalan-hakim-mk\&catid=1:artikelkompas\&Itemid=2 tanggal $1 \overline{9}$ Agustus 2020

${ }_{43}$ Bambang Widjojanto, et al, 2002, Konstitusi Baru Melalui Komisi Konstitusi Independen, Pustaka Sinar Harapan, Jakarta, hlm.148

${ }^{44}$ Saldi Isra, Tim...Loc.Cit.
} 
Selain itu, dalam argumentasinya MK menilai bahwa norma hukum Pasal 15 ayat (2) huruf i tidak memiliki landasan konstitusional yang benar sebagaimana ditentukan Pasal 28J ayat (2) UUD 1945 yang mengatur, "Dalam menjalankan hak dan kebebasannya, setiap orang wajib tunduk kepada pembatasan yang ditetapkan dengan undang-undang dengan maksud semata-mata untuk menjamin pengakuan serta penghormatan atas hak dan kebebasan orang lain dan untuk memenuhi tuntutan yang adil sesuai dengan pertimbangan moral, nilai-nilai agama, keamanan, dan ketertiban umum dalam suatu masyarakat demokratis". Argumentasi MK tersebut juga tidak jelas dan tidak didasari landasan hukum yang kuat bahwa Pasal 15 ayat (2) huruf i bertentangan dengan Pasal 28J ayat (2) UUD 1945, padahal nyata-nyata bahwa Pasal 15 ayat (2) huruf i merupakan elaborasi Pasal 24C ayat (5), "Hakim konstitusi harus memiliki integritas dan kepribadian yang tidak tercela, adil, negarawan yang menguasai konstitusi dan ketatanegaraan, serta tidak merangkap sebagai pejabat negara".

Norma hukum Pasal 15 ayat (2) huruf i tersebut lebih didasarkan pada penghukuman politik. Norma hukum Pasal 15 ayat (2) huruf i tersebut lebih didasarkan pada penghukuman politik terhadap komunitas tertentu dan merupakan stigmatisasi belaka yang dalam penerapannya penuh dengan permasalahan hukum, stigma "menyamakan semua anggota partai politik sebagai calon koruptor dan berkepribadian tercela dan tidak dapat berlaku adil" sehingga tidak memenuhi syarat menjadi Hakim Konstitusi adalah suatu penalaran yang tidak benar". Stigmatisasi seperti ini menciderai hak-hak konstitusional seorang warga negara dan hak untuk menjadi Hakim Konstitusi bagi setiap orang adalah hak dasar untuk ikut dalam pemerintahan yang dijamin oleh UUD 1945.

Terhadap ketentuan di atas dapat digarisbawahi bahwa stigma dalam norma hukum adalah bentuk nyata pelanggaran konstitusional, namun Penulis tidak sependapat jika ketentuan Pasal 15 ayat (2) huruf i dinilai sebagai stigma terhadap komunitas tertentu. Pasal a quo dilatarbelakangi kondisi MK yang terpuruk akibat perilaku mantan ketua MK (AM). Dalam Penjelasan UU MK Perubahan Kedua No.4/2014 disebutkan bahwa pada saat itu kewibawaan dan kepercayaan masyarakat terhadap hakim konstitusi menurun, padahal hakim konstitusi mengemban amanah sangat penting untuk menjaga tegaknya demokrasi dan pilar negara hukum, sehingga perlu dilakukan upaya penyelamatan terhadap hakim konstitusi secara cepat, khususnya menjelang pelaksanaan pemilihan umum 2014 yang sangat strategis bagi keberlanjutan kehidupan demokrasi di tanah air. Jika ketidakpercayaan masyarakat terhadap hakim konstitusi tidak segera dipulihkan akan berimplikasi terhadap legitimasi hasil pemilihan umum 2014 yang sengketanya merupakan kewenangan hakim konstitusi untuk mengadili. ${ }^{45}$

Menurut Ni'matul Huda bahwa lahirnya UU MK Perubahan Kedua No.4/ 2014 diawali dari Peraturan Pemerintah Pengganti Undang-Undang No.1 Tahun 2013 tentang Perubahan Kedua Atas Undang-Undang No.24 Tahun 2003. Perppu MK layak

\footnotetext{
${ }^{45}$ Penjelasan Undang-undang No.4 Tahun 2014 tentang Penetapan Peraturan Pemerintah Pengganti Undang-undang No.1 Tahun 2013 tentang Perubahan kedua atas Undang-Undang No.24 Tahun 2003 tentang Mahkamah Konstitusi menjadi Undang-undang
} 
untuk diapresiasi, karena Perppu MK dikeluarkan oleh Pemerintah dimaksudkan untuk mengembalikan kepercayaan publik terhadap MK akibat adanya kemerosotan integritas dan kepribadian salah satu hakim konstitusi yang kebetulan menjabat sebagai Hakim Konstitusi AM (mantan Ketua MK), yang terjaring 'operasi tangkap tangan. Tertangkapnya AM menimbulkan 'kegaduhan politik' dan kesedihan luar biasa bagi kalangan masyarakat yang selama ini menumpukan harapan besar kepada MK untuk mengawal reformasi dan bangunan negara hukum yang demokratis. Masyarakat sepertinya tidak percaya kalau ternyata di MK pun ada hakim yang tidak bersih dan rela menjatuhkan martabatnya demi uang. MK dibangun dari gagasan besar dan mimpi rakyat Indonesia untuk memiliki rumah keadilan masa depan yang kokoh. Namun apa boleh dikata, skandal suap yang melibatkan mantan Hakim konstitusi AM (Mantan Ketua MK) ini langsung menghancurkan kredibilitas dan legitimasi putusan-putusan yang telah dikeluarkan MK selama ini. Kepercayaan publik runtuh seketika, pencitraan bahwa MK merupakan salah satu lembaga negara yang dianggap steril dari praktik korupsi pun memudar. Citra yang buruk MK saat ini tampaknya juga menghapus fakta bahwa MK pernah berprestasi dalam memutus perkara pengujian undang-undang, sengketa antarlembaga negara, sengketa Pemilu, sengketa pemilihan presiden dan wakil presiden, dan beberapa putusan tentang sengketa Pemilukada. ${ }^{46}$

Uraian di atas menegaskan bahwa konstitusi lahir bertujuan untuk pembatasan kekuasaan dan tidak menghendaki adanya penghukuman politik terhadap komunitas tertentu yang diakibatkan adanya perilaku yang tidak bermoral ketua dan/atau anggota komunitasnya. Namu, penilaian MK bahwa adanya stigma tidak independen yang dijadikan dasar untuk membatalkan Pasal 15 ayat (2) huruf i ini tidaklah tepat. Berdasarkan Pasal 24C ayat (5) UUD 1945, hakim konstitusi harus memiliki integritas dan kepribadian yang tidak tercela, adil, dan negarawan yang menguasai konstitusi dan ketatanegaraan serta tidak merangkap jabatan sebagai pejabat negara. Lebih lanjut, bahwa penegasan syarat hakim konstitusi yang sedemikian ketat dan berat dalam Pasal 15 ayat (2) huruf i karena hakim konstitusi mengemban amanah yang sangat mulia yaitu menegakkan kehidupan berbangsa melalui penjagaan konstitusi sesuai dengan prinsip negara hukum.

Artinya Pasal 15 ayat (2) huruf i "tidak menjadi anggota partai politik dalam jangka waktu paling singkat 7 (tujuh) tahun sebelum diajukan sebagai calon hakim konstitusi" sebagai norma hukum yang bertujuan mengembalikan kredibilitas MK di mata publik justru mengandung manfaat yang lebih besar bagi independensi dan imparsilitas hakim konstitusi. Seharusnya MK tidak membatalkan Pasal 15 ayat (2) huruf i karena pengaturannya lebih baik dari undang-undang sebelumnya, secara tidak langsung pengaturan tersebut dapat berimplikasi pada hasil hakim konstitusi yang lebih independen, imparsial dan berintegritas.

Intinya bahwa Pasal 15 ayat (2) huruf i memberikan solusi (kebemanfaatan) agar dikemudian hari tidak terjadi lagi perilaku hakim konstitusi seperti yang dilakukan oleh

\footnotetext{
${ }^{46}$ Ni’matul Huda, "Problematika...Op.Cit., hlm.13
} 
mantan Ketua MK (AM). Namun karena putusan MK membatalkan Pasal a quo dan tidak adanya upaya hukum lain atas putusan tersebut, maka putusan MK tersebut harus dihargai dan dihormati. Mengutip ungkapan Gustav Radbruch, bahwa terdapat keadilan di luar undang-undang (ubergezets liches recht) dan ketidakadilan undang-undang (gezets liches unrecht). ${ }^{47}$ Dengan mengacu pada ungkapan tersebut, bisa jadi "tidak terdapat keadilan dalam putusan hakim konstitusi". Ke depan MK harus lebih hati-hati dalam menyatakan suatu norma hukum dalam undang-undang bertentangan dengan UUD 1945.

\section{c. Kasus-Kasus Pelanggaran Hukum dan Kode Etik}

Sejak MK berdiri telah terjadi beberapa kasus suap dan pelanggaran kode etik yang menimpa hakim konstitusi. Tabel di bawah ini merupakan daftar kasus-kasus tersebut berdasarkan Putusan Dewan Etik dan MKMK, yaitu:

\begin{tabular}{llll} 
No & Tahun & \multicolumn{1}{c}{ Nama Hakim MK } & \multicolumn{1}{c}{ Kasus } \\
\hline 1 & 2010 & Arsyad Sanusi & Pelanggaran Etik \\
\hline 2 & 2013 & Akil Mochtar & Suap \\
\hline 3 & 2016 & Arif Hidayat & Pelanggaran Etik \\
\hline 4 & 2017 & Patrialis Akbar & Suap \\
\hline 5 & 2018 & Arif Hidayat & Pelanggaran Etik \\
\hline 6 & 2020 & Arif Hidayat, Anwar Usman, & Menerima Gelar Kehormatan \\
& & Aswanto, Wahiddin, Suhartoyo, & dari Presiden di masa aktif \\
& & Manahan & sebagai Hakim \\
\hline
\end{tabular}

Tabel 1. Daftar hakim MK terkena pelanggaran etik dan pidana

Beberapa kasus pelanggaran hukum, moral dan etika dalam kategori ringan adalah kasus hakim konstitusi Arsyad Sanusi dan hakim konstitusi Arief Hidayat. Kasus Hakim Konstitusi Arsyad Sanusi adalah kasus ringan, kasus ini memintanya untuk bertanggung jawab atas pertemuan salah satu keluarga dekatnya dengan pihak yang berperkara di MK. Namun yang dilakukannya adalah mengundurkan diri dari hakim konstitusi. Apa yang dilakukan Arsyad Sanusi adalah tindakan terhormat, preseden yang baik bagi hakim konstitusi yang melanggar kode etik walau pelanggaran tersebut tidak langsung terkait dengannya.

Kasus pelanggaran ringan lainnya adalah kasus memo kontroversial Ketua MK Arief Hidayat kepada mantan Jaksa Agung Muda Pidana Khusus dan kasus pelanggaran kode

\footnotetext{
${ }^{47}$ Kusnu Goesniadhi S, Loc.Cit.
} 
etik sebelum proses uji kelayakan dan kepatutan terkait pencalonannya kembali sebagai hakim konstitusi di DPR. Dalam kasus tersebut Hakim Konstitusi diberikan teguran lisan dan tertulis dari Dewan Etik Mahkamah Konstitusi.Walaupun banyak pihak mengajukan petisi agar Arif Hidayat mundur pada pencalonannya yang kedua karena terkait kasus pelanggaran kode etik tersebut, namun yang bersangkutan bersikukuh meneruskan pencalonan periode keduanya.

Sementara itu, beberapa kasus berat perbuatan tidak bermoral yang dilakukan hakim konstitusi adalah kasus Akil Mochtar dan kasus Patialis Akbar. Dua kasus tersebut menyebabkan MK kehilangan marwahnya dan sekaligus merendahkan martabat hakim konstitusi. Berdasarkan Keputusan Majelis Kehormatan Mahkamah Konstitusi (MKMK) No.011MKMK/XI/2013 bahwa hakim konstitusi Akil Mochtar telah melakukan pelanggaran Kode Etik dan Perilaku Hakim Konstitusi dan menjatuhkan sanksi pemberhentian dengan tidak hormat. Pelanggaran hukum, etika, dan moralitas meliputi: Penyuapan dan tindak pidana pencucian uang.

Hakim Konstitusi Akil Mochtar terbukti bukan seorang negarawan, sebab telah berhasil memanfaatkan kekuasaannya untuk meraup keuntungan/kekayaan sebanyakbanyaknya. Hakim Akil Mochtar terbukti melakukan tindak pidana penyuapan dalam kasus penyelesaian sengketa pilkada di Mahkamah Konstitusi. Kasus ini membuktikan bahwa pendapat Erhard Blankenburg ada benarnya bahwa independensi peradilan dapat diuji melalui dua hal: yaitu ketidakberpihakan (impartiality) dan keterputusan relasi dengan para aktor politik (political insularity). Pemutusan relasi dengan dunia politik penting bagi seorang hakim agar ia tidak menjadi alat merealisasikan tujuantujuan politik. Kasus runtuhnya integritas Akil Mochtar adalah bukti bahwa eratnya hubungan hakim konstitusi dan partai politik yang berdampak pada kasus penyuapan hakim konstitusi dari partai politik yang pernah membesarkan namanya.

Dalam kasus Patrialis Akbar, Majelis Kehormatan Mahkamah Konstitusi No.1/ MKMK-SPL/II/2017 telah menjatuhkan sanksi kepada Patrialis Akbar dengan pemberhentian dengan tidak hormat. Keputusan ini diambil karena yang bersangkutan telah melakukan pelanggaran berat kode etik dan pedoman perilaku hakim konstitusi. Pelanggaran kode etik ini dilatarbelakangi oleh perilaku yang terbukti secara sah dan meyakinkan telah melakukan pertemuan dan/atau pembahasan mengenai perkara yang sedang ditangani antara hakim konstitusi Patrialis Akbar dengan pihak yang berkepentingan dengan perkara, baik langsung maupun tidak langsung di luar persidangan. Selain itu, Patrialis juga terbukti telah membocorkan informasi dan draf putusan MK yang bersifat rahasia. Keputusan MKMK ini diperkuat oleh Mahkamah Agung yang dalam Peninjauan Kembali (PK) menjatuhkan pidana penjara selama 7 tahun dan pidana denda sebesar Rp 300 juta subsider pidana kurungan selama 3 bulan.

Implikasi dari terjadinya kasus-kasus di atas sangatlah berbahaya bagi perkembangan tatanan hukum dan bermasyarakat. Ketika para penegak hukum telah melanggar hukum itu sendiri, lalu masyarakat akan merefleksikan diri mengapa mereka harus mengikuti aturan hukum sedangkan para penegak hukum tidak berlaku adil, dan justru melanggar 
aturan. Hal ini akan menimbulkan kekacauan hukum di masyarakat ${ }^{48}$ dan terjadi distrust kepada lembaga yang sangat vital, yaitu Mahkamah Konstitusi. Prinsip dasar adanya suatu nilai demokratis adalah pentingnya keterlibatan masyarakat dalam pengaturan kelembagaan guna mewujudkan sistem penataan lembaga yang sehat dan demokratis ${ }^{49}$. Lembaga kehakiman yang independen dan imparsial akan memberikan manfaat kepada masyarakat dan masyarakat itu pula yang mengingatkan kepada lembaga tersebut agar tetap netral dan terbebas dari pengaruh-pengaruh internal ataupun eksternal yang bisa melanggar aturan hukum yang berlaku di masyarakat, dan lembaga kehakiman yang independen, berintegras, danakuntabelmerupakannilaiesensidarisebuahnegarahukum. ${ }^{50}$

\section{Alternatif Model Seleksi Hakim MK}

\section{a. Model Terbuka - Sentralistik}

Padamodelini,seluruhcalonhakimkonstitusiakanmelaluitahapanfitandpropertestyang dilaksanakan oleh DPR sebagai lembaga legislatif, setelah diusulkan oleh masing-masing lembaga pengusul. Selanjutnya, hasil dari fit and proper test tersebut akan dikembalikan kepada masing-masing lembaga untuk dilakukannya tahap akhir pemilihan. Selanjutnya, masing-masing lembaga mengusulkan masing-masing 3 nama tersebut kepada Presiden untuk diangkatmenjadi hakim konstitusidengan keputusan presiden. Modelini(Gambar 5) telah diterapkan oleh Korea Selatan dalam melakukan rekrutmen Hakim $\mathrm{MK}^{51}$. Kelebihan pada model ini adalah, semua calon hakim MK yang diusulkan oleh Presdien, DPR, dan MA akan melalui proses fit and proper test secara sentralistik yang dilakukan oleh DPR secara terbuka untuk umum, sehingga partisipasi publik untuk mengetahui dan menggali informasi dan kualitas akan semakin transparan dan terbuka.

Hal ini menjadikan semangat dari demokrasi dan check and balances terlihat secara jelas pada model ini sebab semua kandidat harus melalui proses hearings di DPR. Semua kandidat akan secara tidak langsung, menunjukan kualitas diri dan orang yang bersihlah yang akan tampil. Proses hearings ini akan memastikan integritas dan kapasitas calon hakim. Namun, pada proses ini masih memiliki kelemahan, yaitu belum ada penekanan pada penulusan calon secara aktif melalui silent tracking, karena rekrutmen calon hakim sifatnya pasif yaitu dengan cara pengumuman terbuka.

\footnotetext{
${ }^{48}$ Lihat James E. Moliterno et. al., Independence Without Accountability: The Harmful Consequences of Eu Policy Toward Central and Eastern European Entrants, Fordham International Law Journal, 2018, Vol.42, hlm. 487

${ }^{49}$ Lihat Thomas Tinkham, Applying A Rational Approach to Judicial Independence and Accountability on Contemporary Issues, William Mitchell Law Review, 2011, Vol.37, hlm. 1658

${ }^{50}$ Lihat Oagile Bethuel Key Dingake, Najla Hasic, Tomei Peppard, Stephen Hayden, Appointment of Judges and the Threat to Judicial Independence: Case Studies from Botswana, Swaziland, South Africa, and Kenya, Southern Illinois University Law Journal, 2020, Vol.44, hlm. 412

${ }^{51}$ Hyunchool Lee et al, 2010, How to Improve the Confirmation Hearing in the National Assembly, National

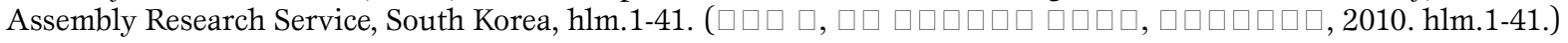




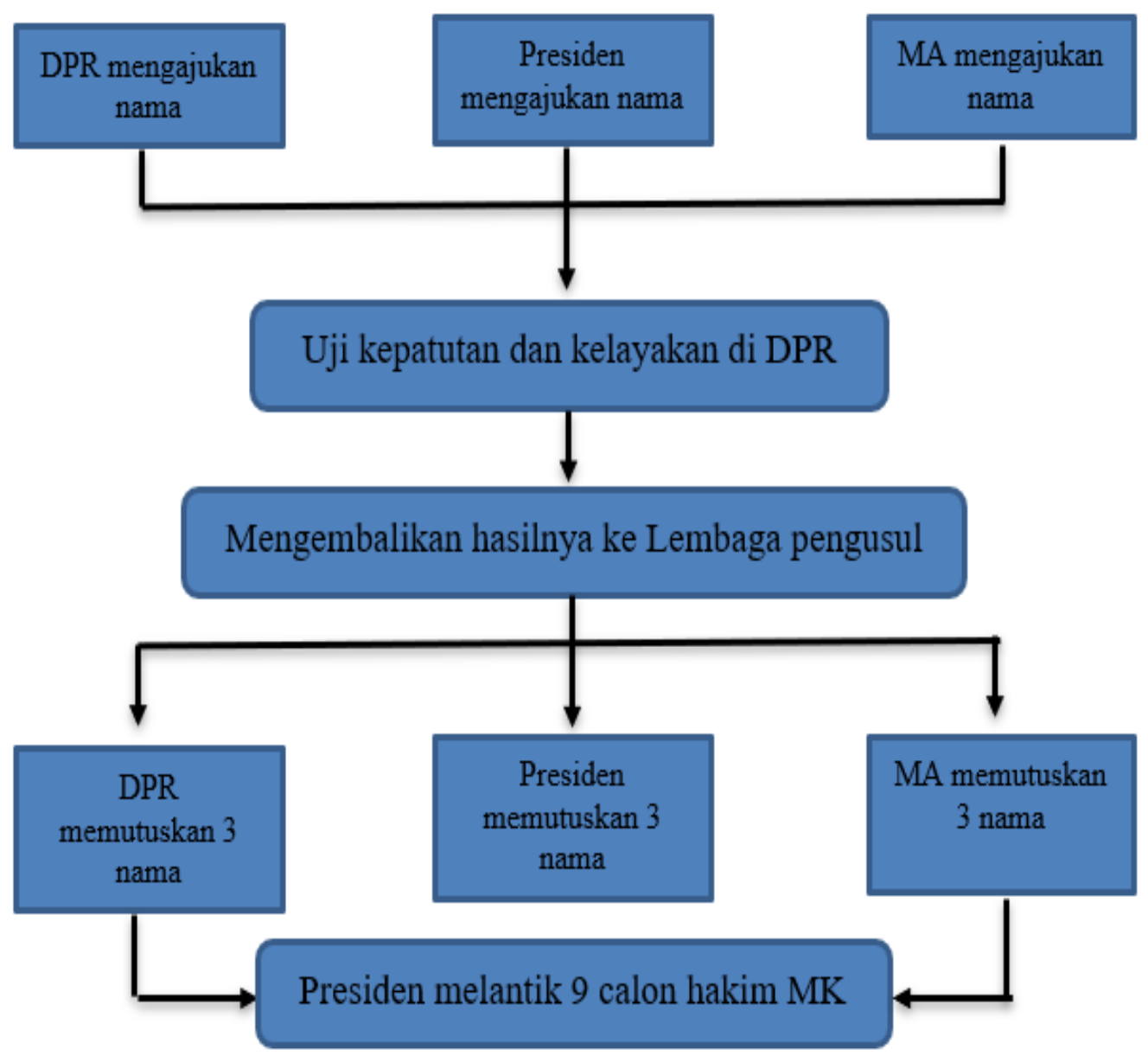

Gambar 5. Model Terbuka - Sentralistik

\section{b. Model Terbuka-Desentralisasi}

Usulan model ini menggunakan prinsip terbuka dan desentralisasi (open and decentralized). Pada model ini, masing-masing lembaga akan melaksanakan fit and proper test nya masing-masing untuk memilih calon kandidat hakim konstitusi. Permasalahan pada model ini adalah kebutuhan akan standar baku dari mekanisme serta aturan pemilihan yang diatur oleh hukum. Di Indonesia, DPR dan Presiden melaksanakan fit and proper test secara terbuka, namun Mahkamah Agung melaksanakannya dengan mekanisme tertutup. Oleh karena itu, pada model ini, baik Presiden, DPR, dan MA dalam melakukan rekrutmen hakim konstitusi harus dilakukan secara terbuka.

Namun kelemahan pada model ini adalah tidak efiesien pada proses fit and proper test karena masing-masing lembaga menyelenggarakan proses fit and proper test secara terpisah. 

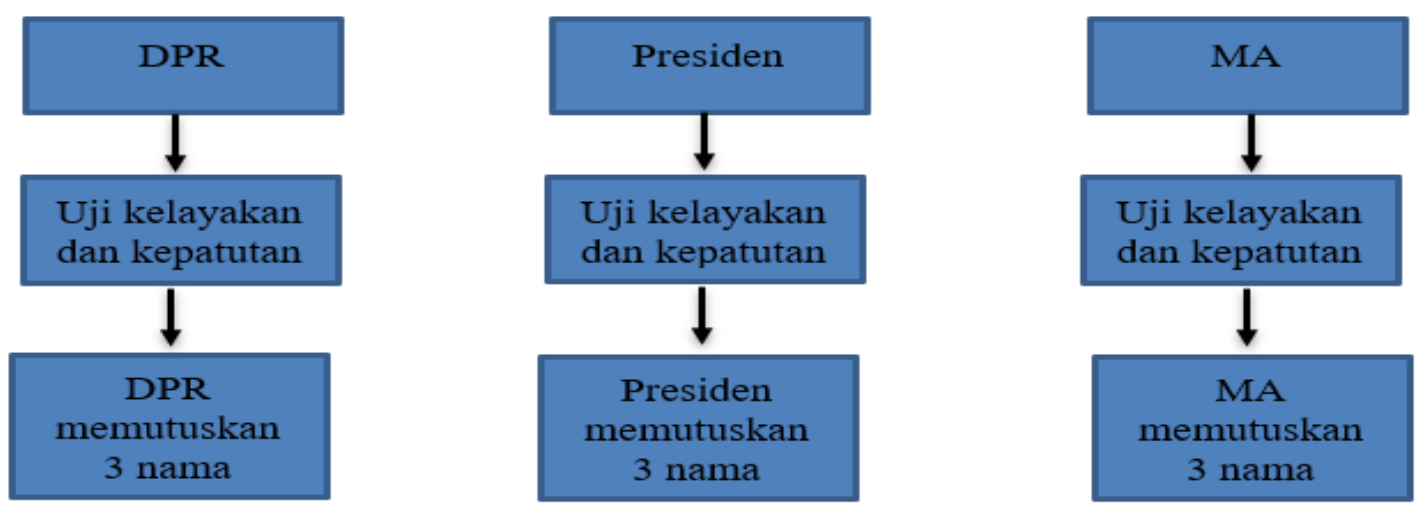

Gambar 6. Model Terbuka-Desentralistik

\section{c. Model Aktif-Pasif-Terbuka-Sentralistik}

Dalam model ini, ada penggabungan cara penulusuran calon hakim, yaitu secara aktif dan pasif. Secara aktif maksudnya adalah masing-masing lembaga pengusul dapat memilih calon yang mereka anggap punya kualifikasi. Sedangkan pasif maksudnya adalah lembaga pengusul tetap membuka pengumuman terbuka pencalonan hakim konstitusi. Setelah lembaga pengusul menggunakan model penulusuran tersebut, maka nama-nama yang dinominasikan selanjutnya dilakukan penelusuran (silent tracking) secara diam-diam untuk memastikan integritas calon.

Setelah lembaga pengusul telah memastikan calon-calon tersebut memiliki integritas, maka daftar nama calon tersebut diserahkan kepada DPR untuk menjalani proses Confirmation Hearings secara terbuka di DPR. Confirmation Hearings ini bertujuan untuk memastikan kapasitas keilmuan calon sesuai kebutuhan menjadi seorang hakim konstitusi. Disamping itu, proses tersebut juga memberikan kepada publik untuk memberikan masukan tentang integritas para calon.

Setelah proses Confirmation Hearings, nama-nama calon hakim khusus dari MA dan Presiden diserahkan kembali kepada lembaga terkait untuk memutuskan calon mana yang akan diusulkan menjadi hakim konstitusi. Kemudian, nama-nama yang telah diusulkan diserahkan kepada Presiden untuk diangkat menjadi hakim konstitusi.

Kelebihan sistem ini adalah pertama, bisa memaksimalkan penelusuran calon-calon hakim terbaik dan lebih memastikan integritas calon hakim konstitusi karena ada proses verifikasi faktual terhadap integritas para calon. Kedua, sistem ini juga memiliki kelebihan publik dapat memberikan masukan maksimal tentang integritas dan kapasitas calon hakim. Namun, model ini memiliki kelemahan karena sangat tergantung pada kualitas leadership masing-masing lembaga pengusul. 


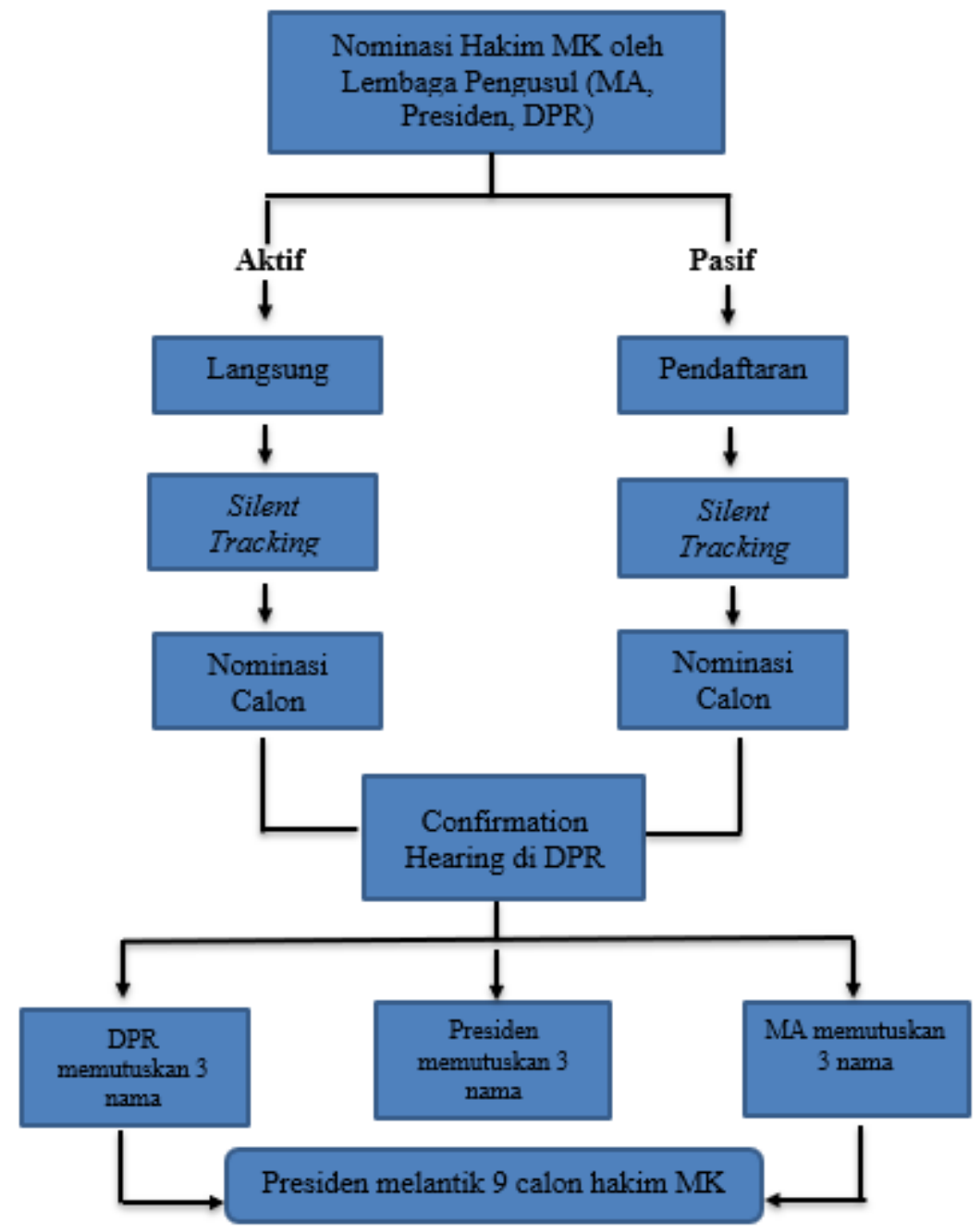

Gambar 7. Aktif-Pasif-Terbuka-Sentralistik

\section{SIMPULAN}

Berdasarkan pembahasan di atas, maka dapat disimpulkan bahwa mekanisme seleksi berimplikasi pada kualitas hakim konstitusi yang dilahirkan oleh mekanisme tersebut, baik dari sisi kapasitas dan integritas. Penelitian ini menunjukkan bahwa hakim-hakim yang terlibat suap dan pelanggaran kode etik merupakan produk dari mekanisme seleksi yang tidak transparan sehingga tidak memiliki integritas yang baik. Hal tersebut dibuktikan dengan kasus-kasus yang terjadi yang menimpa hakim Akil Mochtar, Patrialis Akbar, dan Arief Hidayat di mana mereka masuk sebagai hakim MK melalui proses yang tidak transparan dan akuntabel. Selain itu, rekrutmen Hakim MK yang berasal dari MA dengan sistem yang tertutup, telah memunculkan problem lain terkait kompetensi calon hakim MK yang dianggap tidak sejalan dengan tugas-tugas sebagai hakim konstitusi yang harus memahami konstitusi dengan sangat baik.

Penelitian ini merekomendasikan 2 (dua) hal, pertama, standarisasi mekanisme seleksi hakim konstitusi melalui mekanisme yang terbuka sehingga publik dapat memberikan masukan yang maksimal kepada calon-calon hakim yang diseleksi. Kedua, seleksi hakim 
konstitusi perlu memperhatikan aspek kompetensi yang dibutuhkan di MK. Berdasarkan model alternatif mekanisme seleksi hakim konstitusi pada pembahasan sebelumnya maka penelitian ini lebih merekomendasikan model Aktif-Pasif-Terbuka-Sentralistik (Gambar 7). Model ini lebih mampu menutup kelemahan-kelemahan model rekrutmen hakim MK yang lain. Perubahan model rekrutmen hakim MK tersebut juga berimplikasi pada urgensi adanya perubahan Undang-Undang Mahkamah Konstitusi.

\section{DAFTAR PUSTAKA}

\section{Buku}

A. Muhammad Asrun, (2004), Krisis Peradilan: Mahkamah Agung di bawah Suharto, Elsam, Jakarta

Bambang Widjojanto, et al, (2002), Konstitusi Baru Melalui Komisi Konstitusi Independen, Pustaka Sinar Harapan, Jakarta

Brandon L. Bartels dan Christopher D. Johmston, (2020), Curbing the Court: Why the Public Constraints Judicial Independence, Cambridge University Press, Cambridge

Cora Hoexter, (2018), The Judicial Service Commission: Lessons from South Africa dalam Graham Gee and Erika Rackley, Debating Judicial Appointments in an Age of Diversity, Routledge, London

F. Sugeng Istanto, (2007), Penelitian Hukum, CV. Ganda, Yogyakarta

Hyunchool Lee et al, (2010), How to Improve the Confirmation Hearing in the National Assembly, National Assembly Research Service, South Korea

Johnny Ibrahim, (2005), Teori \& Metodologi Penelitian Hukum Normatif, Bayumedia Publising, Malang

Kaelan, (2002), Pendidikan Pancasila, Paradigma, Yogyakarta

KRHN, (2008), Menggapai Keadilan Konstitusi; Suatu Rekomendasi untuk Revisi UU Mahkamah Konstitusi, Konsorsium Reformasi Hukum Nasional (KRHN), Jakarta

\section{Jurnal}

Aydın, A. (2013). Judicial independence across democratic regimes: Understanding the varying impact of political competition. Law \& Society Review, 47(1), 105-134.

Landsberg, Brian K., (2007), The Role of Judicial Independence, Pacific McGeorge Global Bussiness \& Development Law Journal, Vol.19 No.2

Clyde D. Compton, (2005), An Independent Judiciary, Res Gestae, , Vol.49 No.5

Daniel M. Klerman, (2007), Legal Infrastructure, Judicial Independence, and Economic Development, Pacific McGeorge Global Bussiness \& Development Law Journal, Vol.19 No.2

Farid Suffian Shuaib, (2011), Malaysian Judicial Appointment Process: An Overview of Reform, Journal of Applied Sciences Research, Vol.7 No.13

Feri Amsari, Satjipto Rahardjo (2009), dalam Jagat Ketertiban Hukum Progresif, Jurnal Konstitusi, Vol.6 No.2 
Hendrianto, (2016), The Rise and Fall of Heroic Chief Justices, Constitutional Politics and Judicial Leadership in Indonesia, Washington International Law Journal, Vol.25 No.3

Indramayu, Jayus, (2017), dan Rosita Indrayati, Rekonseptualisasi Seleksi Hakim Konstitusi sebagai Upaya Mewujudkan Hakim Konstitusi yang Berkualifikasi, Lentera Hukum, Vol.4 No.1

James E. Moliterno et. al., (2018), Independence Without Accountability: The Harmful Consequences of EU Policy Toward Central and Eastern European Entrants, Fordham International Law Journal, Vol.42

Joanna M. Shepherd, (2009), Money, Politics, and Impartial Justice, Duke Law Journal, Vol.58

Kusnu Goesniadhie S, (2007), Prinsip Pengawasan Independensi Hakim, Jurnal Hukum, Vol.14 No.3

Louraine C. Arkfeld, (2007), The Rule of Law and an Independent Judiciary, Judges Journal, Vol.46 No.4

Lydia Brashear Tiede, (2006), Judicial Independence: Often Cited, Rarely Understood, Journal of Coontemporary Legal Issues, Vol.15

Ni'matul Huda, (2013), Problematika Substantif Perppu Nomor 1 Tahun 2013 Tentang Mahkamah Konstitusi, Jurnal Konstitusi, Vol.10 No.4

Oagile Bethuel Key Dingake, Najla Hasic, Tomei Peppard, Stephen Hayden, (2020), Appointment of Judges and the Threat to Judicial Independence: Case Studies from Botswana, Swaziland, South Africa, and Kenya, Southern Mlinois University Law Journal, Vol.44

Puguh Windarawan, (2012, Pergeseran Kekuasaan Tipologi Ketiga: Fenomena Kekuasaan Kearah Constitusional Heavy, Jurnal Konstitusi, Vol.9 No.4

Reid Mortensen dan Richard Devlin, Special Issue, (2017), The Ethics of Judicial Appointments, Legal Ethics, Vol 20 No. 1

Rifqi Sjarief Asegaf, (2002), Hanya Hakim yang Bersih dan Kompeten yang Layak Adili Koruptor, Jurnal Kriminologi Indonesia, Vol.2 No.1

Samuel Spac, (2018), Recruiting of European Judges in the Age of Judicial SelfGovernment, German Law Journal, Vol.19 No.5

Shirley S. Abrahamson, (2005), Judicial Independence as A Campaign Platform the Importance of Fair and Impartial Courts, Michigan Bar Journal, Vol.84

Stephen B. Burbank, (2013), What Do We Mean by "Judicial Independence"?, Ohio State Law Journal, Vol.64

Taufiqurrohman Syahuri, (2010), Problematika Tugas Konstitusional Komisi Yudisial, Jurnal Konstitusi, Vol.7 No.4

Terri Peretti, (2003), A Normative Appraisal of Social Scientific Knowledge Regarding Judicial Independence, Ohio State Law Journal, Vol.64

Thomas Tinkham, (2011), Applying A Rational Approach to Judicial Independence and Accountability on Contemporary Issues, William Mitchell Law Review, Vol.37 
Winda Wijayanti, Nuzul Quraini M, Siswantana Putri R, (2015), Transparansi dan Partisipasi Publik dalam Rekrutmen Calon Hakim Konstitusi, Jurnal Konstitusi, Vol.12, No.4.

\section{Putusan Pengadilan dan Peraturan Perundang-Undangan}

Putusan MK No.1-2/PUU-XII/2014

Putusan MK No.81/PUU-IX/2011

Penjelasan Undang-undang No.4 Tahun 2014 tentang Penetapan Peraturan Pemerintah Pengganti Undang-undang No.1 Tahun 2013 tentang Perubahan kedua atas Undang-Undang No.24 Tahun 2003 tentang Mahkamah Konstitusi menjadi Undang-undang

\section{Internet}

Abba Gabrilin, 2017, Patrialis Akbar Ditangkap bersama Seorang Perempuan di Grand Indonesia, https://nasional.kompas.com/read/2017/01/26/20172511/patrialis. akbar.ditangkap.bersama.seorang.perempuan.di.grand.indonesia, diakses pada 20 September 2020

Andi Saputra, 2016, Tanpa Seleksi yang Transparan, Hakim Konstitusi Anwar Usman Dipertanyakan, https://news.detik.com/berita/d-3182850/tanpa-seleksi-yangtransparan-hakim-konstitusi-anwar-usman-dipertanyakan diakses pada 18 Maret 2021

Ihsanuddin, 2013, Akil Mochtar Ditangkap, Hakim dan Mantan Hakim MK Berembuk, https://nasional.kompas.com/read/2013/10/03/2041208/Akil.Mochtar. Ditangkap.Hakim.dan.Mantan.Hakim.MK.Berembuk, diakses pada 20 September 2020

Saldi Isra, Tim pakar dan Pengisian Hakim Konstitusi, diakses dari http://www.saldiisra. web.id/index.php? option $=$ com_content\&view $=$ article\&id $=566$ :tim-pakar-apengisian-hakim-konstitusi tanggal 25 Juli 2020

Saldi Isra, Selamatkan Jalan Hakim MK, diakses dari http://www.saldiisra.web.id/ index.php?option $=$ com_content\&view $=$ article\&id $=565$ :selamatkan-jalanhakim-mk\&catid = 1:artikelkompas\&Itemid $=2$ tanggal 19 Agustus 2020

Sania Mashabi, 2020, Penganugerahan Bintang Mahaputera pada 6 Hakim MK Dinilai Berpotensi Pengaruhi Independensi, https://nasional.kompas.com/ $\mathrm{read} / 2020 / 11 / 12 / 22110041 /$ penganugerahan-bintang-mahaputera-pada-6hakim-mk-dinilai-berpotensi?page = all, diakses pada 25 Nopember 2020

Syamsuddin Radjab, 2017, Cacat Hukum Pemilihan Hakim Konstitusi, https:// antikorupsi.org/id/article/cacat-hukum-pemilihan-hakim-konstitusi, diakses pada 18 Maret 2021 